\title{
Trends in abundance of wintering waterbirds relative to rainfall patterns at a central California estuary, 1972-2015
}

\author{
Lynne E. Stenzel ${ }^{1}$ and Gary W. Page ${ }^{1}$
}

\begin{abstract}
During winter, habitat for waterbirds in California comprises primarily coastal estuaries, whose water resources are consistent, and inland wetlands and agricultural lands, both of which are highly dependent on or influenced by annual precipitation. At Bolinas Lagoon, a shallow central California estuary, we monitored the numbers of waterbirds in winter during two periods, 1972-1993 and 1998-2015, and used generalized linear models to investigate the relationship between levels of annual precipitation and patterns of abundance for 42 taxa. The regional extent of rice fields flooded in the Central Valley in the late fall increased substantially in the 1990s. Anticipating that waterbird distributions might shift in response to this increase in habitat, we structured models to detect changes between the two census periods in trends at Bolinas Lagoon. We found a significant relationship between abundance and rainfall within the winter that abundance was measured for 19 taxa (14 negative, 5 positive). Abundance was related to annual rainfall during the previous $1-4$ years for 28 taxa (18 negative, 10 positive), and only 7 taxa showed no relationship between abundance and rainfall. We found a significant linear trend in the abundance of 39 of the 42 taxa during one (12 taxa, 29\%) or both (27 taxa, 64\%) census periods. Thus a positive or negative trajectory, adjusted for rainfall, was more frequent than a lack of trend. In 14 taxa the trend in the two survey periods differed; 12 of these increased from 1972 to 1993 but then decreased after 1997, a pattern consistent with a distributional shift from the lagoon to newly created inland habitat. Among 22 taxa that regularly used rice fields flooded after harvest, the pattern of 12 was consistent with a distributional shift away from Bolinas Lagoon, whereas that of only 6 was inconsistent with such a shift. Almost twice as many species increased at Bolinas Lagoon from 1972 to 1993 than decreased, whereas the opposite was true from 1998 to 2015. In a comparison of species foraging intertidally versus subtidally, the proportion increasing or decreasing at Bolinas Lagoon did not differ significantly, despite pronounced changes in the lagoon's bathymetry over the 43 years of study. In only 8 of the 26 taxa for which regional data were available was the regional trend consistent with the local trend at Bolinas Lagoon. Our study underscores the importance to monitoring and conservation programs of identifying key drivers of species' abundance at individual sites and understanding how waterbirds respond to local and regional habitat changes.
\end{abstract}

Keywords: Bolinas Lagoon, census, habitat, precipitation, proxy wetlands, rice fields, shorebirds, waterfowl, wetlands

$\mathrm{L}$ ocal abundances are the basic components of regional and global population sizes. Although population trends must be measured at large geographic scales if changes in demography and in distribution are to be detected, long-term data from local sites can provide insight into processes at larger spatial scales. Changes in abundance and species composition at a local site can reflect a combination of factors influencing the constituent populations at local, regional, and global levels

(Musil et al. 2011). Thus identifying the key factors that drive local abundance is important for guiding population monitoring and conservation at all spatial scales.

Estuaries along the central California coast provide important habitats for a wide variety of wintering waterbirds, the majority of which migrate from breeding ranges elsewhere in North America (Bollman et al. 1970, Shuford et al. 1989, Colwell 1994, Kelly and Tappen 1998,

Full citation: Stenzel, L. E., and Page, G. W. 2018. Trends in abundance of wintering waterbirds relative to rainfall patterns at a central California estuary, 1972-2015, in Trends and traditions: Avifaunal change in western North America (W. D. Shuford, R. E. Gill Jr., and C. M. Handel, eds.), pp. 236-257. Studies of Western Birds 3. Western Field Ornithologists, Camarillo, CA; doi $10.21199 /$ SWB3.13.

1Point Blue Conservation Science, 3820 Cypress Drive Suite 11, Petaluma, CA 94954; corresponding author: 1stenzel@pointblue.org 
Page et al. 1999). At one of these estuaries, Bolinas Lagoon, a shallow tidal embayment at the southern end of the Point Reyes Peninsula on the central California coast (Figure 1), waterbird populations have been monitored since the 1970 s (Page et al. 1979, Shuford et al. 1989). The number of migratory birds wintering at a site such as Bolinas Lagoon is a function of the size of source populations and their distributions within their winter range. Size of the source population, the primary interest of many large-scale monitoring projects, is determined by the basic demographic parameters of fecundity and survival at each life stage. Distribution during the nonbreeding season is determined by a combination of factors, including geographic range, the distribution of suitable habitat, and the extent and quality of habitat at the sites constituting the range.

In addition to changes in the size of the source population, factors both intrinsic and extrinsic to a site may influence the number of individuals using that site over time. For example, changes in habitat extent, available food, risk of predation (Page and Whitacre 1975, Kus et al. 1984, Cresswell and Whitfield 1994), or disturbance (Moore and Black 2006) may alter a site's importance for a given species. Similarly, the quantity and quality of habitat in the site's surrounding

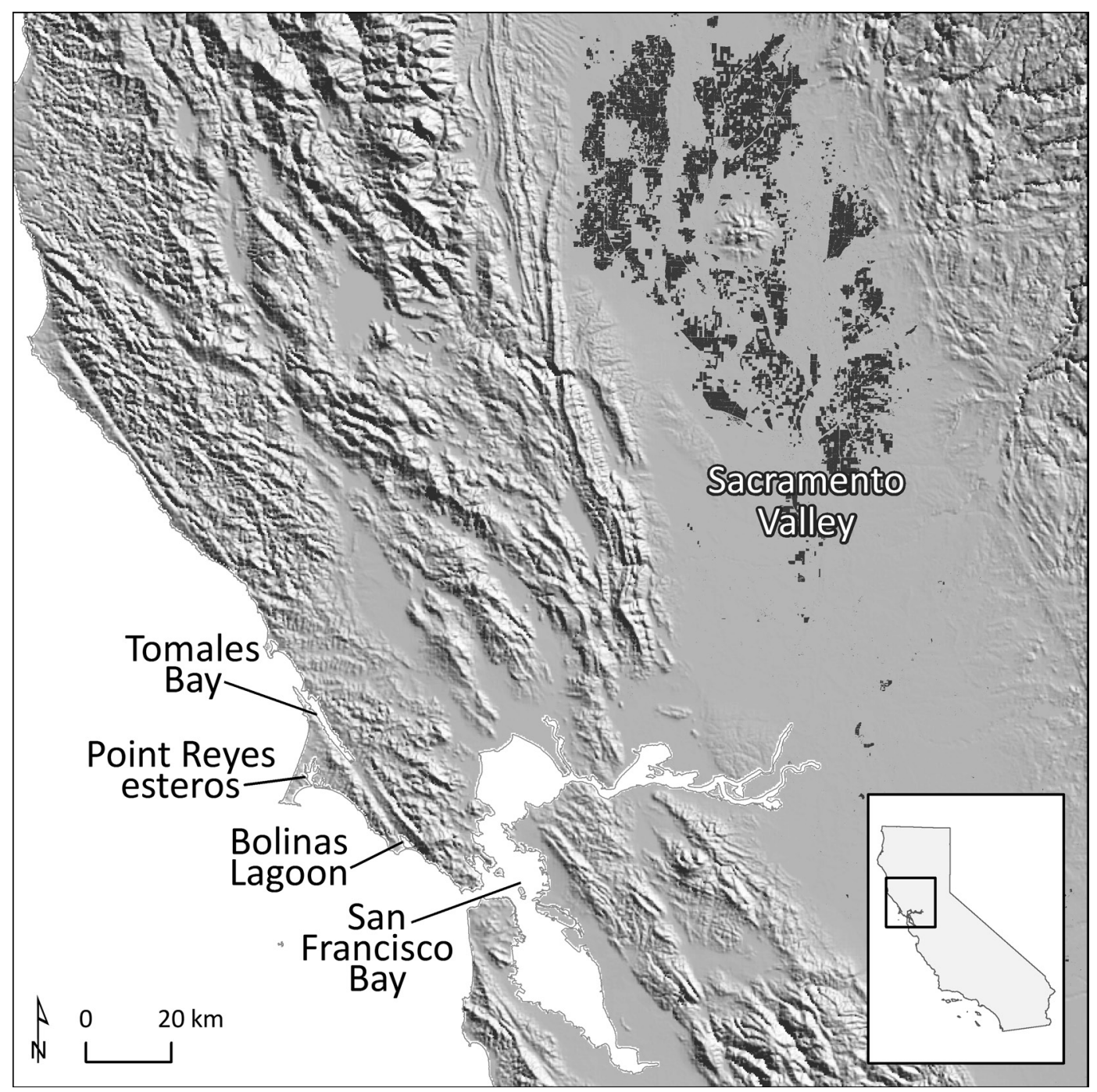

Figure 1. Central California, showing Bolinas Lagoon in relation to Point Reyes esteros, Tomales and San Francisco bays, and the northern and central portions of the Central Valley. Rice-growing areas in the Sacramento Valley are shown as dark shading. 
region may change. And, although winter site fidelity is common in waterbirds, many wetland species exhibit considerable vagility in response to changing conditions at both local and regional levels (Robertson and Cooke 1999, Fleskes et al. 2002, Sanzenbacher and Haig 2002, Lank et al. 2003). Such responses may result in temporary or permanent shifts in distribution (Warnock et al. 1995, 1997; Austin and Rehfisch 2005; Fleskes et al. 2018).

In this study, we analyzed the results of longterm winter censuses of waterbirds at Bolinas Lagoon to better understand potential factors influencing the abundance and distribution of waterbirds wintering in central California. We chose to focus on the winter period because yearround census data from the 1970 s revealed that (1) the numbers of individuals and species of waterbirds in the lagoon were generally highest in winter (Page et al. 1979, Shuford et al. 1989), and (2) winter was the period of least migratory movement by waterbirds at Bolinas Lagoon and nearby estuaries. The censuses initially summarized in those two papers commenced in winter 1972-73, continued until 1992-93, then resumed again from winter 1998-99 through 2014-15. It is these two series of data from Bolinas Lagoon that form the basis for our analyses here.

We were particularly interested in understanding how local and regional factors, including climatic conditions and availability of important habitats, may have influenced annual variation in the abundance of waterbirds wintering at Bolinas Lagoon. At the local level, Shuford et al. (1989) had shown that the numbers of a few species using the lagoon in winter were higher during periods of drought, and they found that birds departed from the lagoon earlier during winters with extended periods of rainfall. Storms and rainfall can affect waterbird numbers at Bolinas Lagoon in several ways. During major rainstorms, the increased ocean swell and runoff from the watershed cause water levels in the lagoon to rise and flood the entire intertidal zone to a level that prevents normal drainage at low tide. These storm-augmented tides prevent birds from feeding in the intertidal zone for more than a day (Shuford et al. 1989). Variation in the flow of fresh water into marine habitats near shore can also affect birds foraging subtidally, by reducing the abundance and availability of their prey (Nichols 1985, Drinkwater and Frank 1994, Moyle 1995, Attrill et al. 1996, Kimmerer 2002, Henkel 2006). The amount of rainfall alone can also affect the abundance and distribution of waterbirds. In a long-term study of estuarine wetlands in southwest India, Aarif et al. (2014) found that high rainfall in a given year and in the previous year resulted in lower counts of shorebirds at a given site, likely because of changes in food resources associated with alteration of the habitats and changes in nutrients in the environment.

Besides drought and intertidal flooding related to precipitation, a third local factor potentially affecting waterbirds wintering in Bolinas Lagoon involves recent physiographic changes to the lagoon itself. Importantly, since the last major earthquake in the region in 1906, the lagoon has lost approximately a third of its tidal prism (the average volume of water exchanged on tidal cycles). The associated steady accretion of sediments has resulted in a gradual increase in salt marsh and high intertidal habitat and a loss of subtidal and low intertidal habitat (MCOSD 2006). Other anthropogenic changes to habitats at and adjacent to Bolinas Lagoon, occurring primarily before the 1990s, may also have affected wintering birds (see Study Area for details).

In addition to local factors, we were also interested in regional factors that may have influenced long-term changes in populations of waterbirds wintering at Bolinas Lagoon. At the regional level, changes to central California's wetlands beginning in the 1990s and restoration of former tidal wetlands around San Francisco Bay and at Tomales Bay likely had the greatest influence on the local and regional distribution of waterbirds. In all areas, but mostly in the Central Valley, within 150 $\mathrm{km}$ of Bolinas Lagoon, the amount of wetland or irrigated agricultural fields available to waterbirds increased dramatically. Most notably, in the Sacramento Valley, a transition from burning to flooding of rice fields after harvest resulted in more than 140,000 ha of shallowly flooded fields attractive to waterbirds (Elphick and Oring 1998, Fleskes et al. 2005, California Rice Commission 2012, Strum et al. 2013). Since flooding of these fields is not dependent on winter rains, the fields were particularly attractive to waterbirds arriving in late fall and early winter.

Beginning in the mid-1990s, tidal action has been restored to wetlands in San Francisco Bay that had been diked for over a century and used primarily as solar salt-evaporation ponds, secondarily for agriculture (Williams and Faber 2001, Beth Huning it litt.). Salt ponds provided habitat value as proxy wetlands in San Francisco Bay, supporting many waterbird species, often in high numbers (Anderson 1970, Takekawa et al. 2001, Warnock et al. 2002). The restoration of former 
salt ponds to tidal action frequently represented a conversion of one habitat type (e.g., nontidal saline ponds) to another (e.g., intertidal flats); subsequently, successional processes led to changes in the composition and abundance of waterbirds using the newly created habitats. These changes could have affected all species that currently forage on intertidal habitats in Bolinas Lagoon, as well as some that formerly foraged in salt ponds throughout the tidal cycle (Warnock et al. 2002, Athearn et al. 2009). More recently, 60-year-old diked pastures at Tomales Bay, only $22 \mathrm{~km}$ from Bolinas Lagoon, were restored to tidal action in 2008 (Kelly and Condeso 2017).

Newly converted or restored tidal habitats in the San Francisco Bay estuary and in Tomales Bay cover approximately 20 times the area of Bolinas Lagoon. Since the restoration of a substantial portion of the tidal habitat restored in the region involved conversion of one wetland type to another, the potential effects on regional waterbird distribution were complex, and investigating them required information we did not have. Therefore, we acknowledge their possible effect on population trends at Bolinas Lagoon but did not include them specifically in our analyses. Generally, however, the nature of central California's regional wetland landscape has been greatly modified and, because of the change in the treatment of rice fields after harvest, the area changed was substantially more extensive during the later census period (1998-99 to 2014-15) than during the early census period (prior to 1993). Such changes could have enabled waterbirds to spread more widely across central California, reducing the abundance of some species at Bolinas Lagoon itself. Studies of marked birds have demonstrated that individuals can readily respond to changes in habitat conditions at this scale (Warnock et al. 1995, Fleskes et al. 2002, Takekawa et al. 2002). For example, Warnock et al. (1995) found not only that 9 of 10 radio-tagged Dunlin moved back and forth between Bolinas Lagoon and central San Francisco Bay to forage during winter, but also that at least 4 of the 10 moved up to $140 \mathrm{~km}$ to the Sacramento-San Joaquin River Delta or the Sacramento Valley after heavy rainfall.

In this paper, we examine population trends of 42 taxa of waterbirds recorded during comprehensive winter censuses at Bolinas Lagoon during the periods 1972-1993 and 1998-2015 in the context of predictions about key factors operating at local and regional scales. First, we predicted that rainfall during a given winter and potentially in previous years should affect the numbers of waterbirds using Bolinas Lagoon in that winter. On the basis of earlier studies at Bolinas Lagoon (Page et al. 1979, Shuford et al. 1989), we predicted that the abundance of species that forage on intertidal habitats should be reduced during winters with heavy rainfall. We hypothesized that prior years' rainfall, particularly multi-year droughts, might also affect waterbird numbers at Bolinas Lagoon, but the direction of the possible effects was unclear. Second, we predicted that, because of the steady accretion of sediment within Bolinas Lagoon, the long-term trend should be more negative for species foraging primarily in subtidal habitats and more positive for species foraging primarily in intertidal habitats. Third, we predicted that some species, particularly those that use flooded rice fields, should have decreased at the lagoon after the mid-1990s, as birds exploit the substantial increase in the regional extent of such fields. To examine birds' potential response to factors operating at different temporal and spatial scales, we constructed models of abundance at Bolinas within a winter and in successive winters relative to that winter's and previous years' rainfall, and we distinguished trends for the 21-year period prior to winter 1993-94 from those for the 17-year period after winter 1997-98. Finally, to understand potential influences of factors operating at larger spatial scales, we examined long-term population trends at Bolinas for concordance with regional trends reported by other sources.

\section{STUDY AREA AND METHODS}

Bolinas Lagoon is a 445-ha seasonal estuary, comprising channels, shallow subtidal basins, intertidal flats, and salt marsh. Fresh water from surrounding creeks typically flows in between November and April. The estuary is bordered mostly by undeveloped grassland, coastal scrub, forest, agricultural land, and two small towns. The next nearest estuaries are the esteros of Point Reyes and Tomales Bay, approximately $22 \mathrm{~km}$ to the northwest and north-northwest, respectively, and the much larger San Francisco Bay estuary, of which the nearest point is approximately $17 \mathrm{~km}$ east of Bolinas Lagoon (Figure 1).

Human activities during the early phase of censuses caused sometimes abrupt habitat change in the lagoon or at its periphery. For example, a plant treating the sewage of the town of Bolinas became operational in 1975, and the discharge of raw sewage into the mouth of the lagoon during outgoing tides was terminated. Toward the end of the 1980s, the grazing of livestock on salt and sedge marshes on the plain of Pine Gulch Creek, the lagoon's 
primary affluent, was discontinued. Subsequently, formerly grazed areas were replaced by ruderal fields, row crops, and, along Pine Gulch Creek, riparian forest. Also in the 1980 s, commercial hydraulic harvesting of ghost shrimp (Neotrypaea californiensis) in the lagoon was discontinued; ghost shrimp are important prey for some of the lagoon's shorebirds (Stenzel et al. 1976).

While isolated from other estuaries, Bolinas Lagoon is not a closed system, either spatially or temporally, for waterbirds in winter (Table 1). This is evident from their movement among central California's wetlands, previously referenced, and from local movements of waterbirds from the lagoon to nearby habitats. These habitats include the outer coast, nearshore waters, fields on which treated waste water is sprayed $1 \mathrm{~km}$ west of the lagoon, and grazed pastures $1-2 \mathrm{~km}$ west of it (Table 1; Page et al. 1979, Warnock et al. 1995). Because many birds move from the lagoon to outlying habitats in response to the rising tide (Page et al. 1979), we censused before tidally driven departures from the estuary. However, birds sometimes departed before the end of a census in response to factors that accelerated tidal inundation, such as low barometric pressure and rainfall (Kelly et al. 2002), to raptors, or to other disturbances. Also, some species arrived or departed for the season within our November-February survey period (Shuford et al. 1989, Point Blue unpubl. data). The lack of closure for the lagoon's populations within a season complicated the analyses of abundance because absences introduced zeros to the data.

\section{Census Methods}

We defined the study year as 1 June to 31 May, using 3 November to 29 February as the winter census period, and surveyed no more than once per 15-day period within each winter. We conducted all censuses on moderate rising tides (1.3$1.7 \mathrm{~m}$ above mean lower low water), conditions under which many species move toward observers as mudflats are inundated. We scheduled censuses for weekdays, on suitable tides, and generally before noon; these conditions occur for 1-2 days, twice each month. Because no more than one census took place in any 15-day period, censuses were fairly evenly spread over each winter. We tried to census at least twice in November-December and twice in January-February, but usually did so three times in the earlier months. There were no censuses between the winters of 1993-94 and 1997-98.

Our censuses encompassed all bird families commonly associated with marine, estuarine, or other wetland habitats and concentrated on those species that forage for a significant proportion of the time that they use Bolinas Lagoon. Because of the estuary's size, we divided it into subsections covered by teams of one or more persons, at least one of which was experienced with species identification and counting techniques and equipped with binoculars and a spotting scope. Counters moved around the high-tide line at the margin of their subsections so that they were opposite each other at boundaries whenever possible. The initial division of the lagoon into three survey areas was based on the lagoon's bathymetric configuration, the distribution of birds, and suitable observation locations so that counts in the three subsections could be completed in 2 to 2.5 hours. As the bathymetry of the tidal flat changed over the course of the study, shifting the positions and size of mudflats and channels, it became necessary to cover one of the subsections with two teams in later years. Teams tried to avoid double-counting by conferring after counts on flock movements, particularly for smaller shorebirds and dabbling ducks; in later years, counters in different subareas conferred in real time by cell phones or two-way radios. In addition to covering the lagoon's tidal areas, we also walked the outer beach of the sandspit separating the lagoon from the ocean to count (only) Snowy Plovers, since most of those using the lagoon spent much of their time (under survey conditions) roosting in flocks on the beach.

\section{Data AnAlyses}

We included a species in our analyses if it met the criterion of $>20$ individuals on at least one census, with the following exceptions. We excluded gulls, which largely roosted in the lagoon and foraged in the nearby ocean, because we sometimes could not identify all individuals to species while also surveying other waterbirds, and because we did not count gulls at all for several years. We excluded the Brown Pelican (Pelecanus occidentalis), which arrives on the lagoon after breeding and stays variably through late fall into winter, because it posed particular problems for modeling, problems due to a predominance of large outliers in the winter survey totals. We also excluded rails, bitterns, the Green Heron (Butorides virescens), and Wilson's Snipe (Gallinago delicata), as our field methods were more appropriate for birds using open habitats. Forty-two taxa, including three species pairs (scaup spp., large grebe spp., and dowitcher spp.) met our criteria for trend analysis. Scientific names of treated species are in Table 1. 


\section{Trends in Abundance of Wintering Waterbirds Relative to Rainfall Patterns}

TABLE 1. Focal species for analysis of trends in abundance during winter at Bolinas Lagoon, California, during two periods, 1972-1993 and 1998-2015, categorized by primary feeding habitat at the lagoon, use of other habitats near the lagoon, and late fall and winter occurrence in Central Valley (CV) rice fields. Species categorized as foraging primarily in intertidal habitat take their prey from the surface or below the surface of mud or sand within the intertidal zone; species categorized as foraging primarily in subtidal habitat take their prey from the water column, including the surface of the substrate in subtidal habitat. Taxa temporarily leaving Bolinas Lagoon for habitats nearby include those for which departures include all (A) or part of $(\mathrm{P})$ the individuals on the lagoon, as observed by local experts. Grazed pastures and ponds on which treated waste water was sprayed are located 1-2 km west of the lagoon; outer coast includes ocean-facing beach and shoreline of soft shale reef; near shore includes ocean waters.

\begin{tabular}{|c|c|c|c|c|c|c|}
\hline \multirow[b]{2}{*}{ Species } & \multirow[b]{2}{*}{$\begin{array}{c}\text { Foraging } \\
\text { habitat }\end{array}$} & \multicolumn{4}{|c|}{ Nearby habitats used } & \multirow[b]{2}{*}{$\begin{array}{l}\text { Use of CV } \\
\text { rice fields } s^{a}\end{array}$} \\
\hline & & $\begin{array}{c}\text { Grazed } \\
\text { pastures }\end{array}$ & $\begin{array}{l}\text { Sewage } \\
\text { ponds }\end{array}$ & $\begin{array}{l}\text { Outer } \\
\text { coast }\end{array}$ & $\begin{array}{l}\text { Near } \\
\text { shore }\end{array}$ & \\
\hline Canada Goose Branta canadensis & intertidal & P A & P A & & & $\mathrm{R}$ \\
\hline Gadwall Anas strepera & intertidal & & $\mathrm{P}$ & & & $\mathrm{R}$ \\
\hline Eurasian Wigeon $A$. penelope & intertidal & $\mathrm{P}$ & $\mathrm{P}$ & & & $\mathrm{R}$ \\
\hline American Wigeon $A$. americana & intertidal & $\mathrm{P}$ & $\mathrm{P}$ & & & $\mathrm{R}$ \\
\hline Mallard A. platyrhynchos & intertidal & & & & & $\mathrm{R}$ \\
\hline Northern Shoveler A. clypeata & intertidal & & $\mathrm{P}$ & & & $\mathrm{R}$ \\
\hline Northern Pintail A. acuta & intertidal & & & & & $\mathrm{R}$ \\
\hline Green-winged Teal A. crecca & intertidal & & $\mathrm{P}$ & & & $\mathrm{R}$ \\
\hline Canvasback Aythya valisineria & subtidal & & & & & $\mathrm{r}$ \\
\hline Scaup spp. A. marila and A. affinis & subtidal & & & & & \\
\hline Surf Scoter Melanitta perspicillata & subtidal & & & & $\mathrm{P}$ & \\
\hline White-winged Scoter $M$. fusca & subtidal & & & & & \\
\hline Bufflehead Bucephala albeola & subtidal & & & & $\mathrm{P}$ & $\mathrm{r}$ \\
\hline Common Goldeneye B. clangula & subtidal & & & & $\mathrm{P}$ & \\
\hline Red-breasted Merganser Mergus serrator & subtidal & & & & $\mathrm{P}$ & \\
\hline Ruddy Duck Oxyura jamaicensis & subtidal & & & & & $\mathrm{r}$ \\
\hline Pied-billed Grebe Podilymbus podiceps & subtidal & & & & & $\mathrm{R}$ \\
\hline Horned Grebe Podiceps auritus & subtidal & & & & & \\
\hline Eared Grebe P. nigricollis & subtidal & & & & & $\mathrm{r}$ \\
\hline Large grebe spp. Aechmophorus occidentalis and A. clarkii & subtidal & & & & & $\mathrm{r}$ \\
\hline Double-crested Cormorant Phalacrocorax auritus & subtidal & & & $\mathrm{P}$ & $\mathrm{P}$ & $\mathrm{r}$ \\
\hline Great Blue Heron Ardea herodias & subtidal & & & & & $\mathrm{R}$ \\
\hline Great Egret $A$. alba & subtidal & & & & & $\mathrm{R}$ \\
\hline Snowy Egret Egretta thula & subtidal & & & & & $\mathrm{R}$ \\
\hline Black-crowned Night-Heron Nycticorax nycticorax & subtidal & & $\mathrm{P}$ & & & $\mathrm{R}^{b}$ \\
\hline American Coot Fulica americana & intertidal & & & & & $\mathrm{R}$ \\
\hline American Avocet Recurvirostra americana & intertidal & & & & & $\mathrm{R}$ \\
\hline Black-bellied Plover Pluvialis squatarola & intertidal & PA & & $\mathrm{P}$ & & $\mathrm{R}$ \\
\hline Snowy Plover Charadrius nivosus & intertidal & & & P A & & \\
\hline Killdeer C. vociferus & intertidal & $\mathrm{P}$ & $\mathrm{P}$ & & & $\mathrm{R}$ \\
\hline Whimbrel Numenius phaeopus & intertidal & & & $\mathrm{P}$ & & \\
\hline Long-billed Curlew $N$. americanus & intertidal & & & $\mathrm{P}$ & & $\mathrm{R}$ \\
\hline Marbled Godwit Limosa fedoa & intertidal & $\mathrm{P}$ & & $\mathrm{P}$ & & \\
\hline Black Turnstone Arenaria melanocephala & intertidal & & & P A & & \\
\hline Sanderling Calidris alba & intertidal & & & P A & & \\
\hline Dunlin C. alpina & intertidal & PA & P A & P A & & $\mathrm{R}$ \\
\hline Least Sandpiper C. minutilla & intertidal & P A & $\mathrm{P}$ & $\mathrm{P}$ & & $\mathrm{R}$ \\
\hline Western Sandpiper C. mauri & intertidal & & $\mathrm{P}$ & $\mathrm{P}$ & & $\mathrm{r}$ \\
\hline Dowitcher spp. Limnodromus griseus and L. scolopaceus & intertidal & $\mathrm{P}$ & $\mathrm{P}$ & $\mathrm{P}$ & & $\mathrm{R}$ \\
\hline Greater Yellowlegs Tringa melanoleuca & subtidal $c$ & & $\mathrm{P}$ & & & $\mathrm{R}$ \\
\hline Willet T. semipalmata & intertidal & & & & & \\
\hline Forster's Tern Sterna forsteri & subtidal & & & & P A & \\
\hline
\end{tabular}

${ }^{a}$ Regular (R) or uncommon/irregular (r) winter use of rice fields flooded after harvest based on Table 1 in Elphick and Oring (1998).

bUse of rice fields by night-herons likely understated, as primarily nocturnal.

${ }^{c}$ Categorized as foraging subtidally because of its prevailing habit of feeding from the water column and its prominent use of the edge of water bodies, even when tidal flat is scarce or absent. 
We obtained rainfall data from Point Blue's Palomarin Field Station, approximately $3.5 \mathrm{~km}$ west of the lagoon. To test the hypothesis that rainfall, as it accumulates through the late fall and winter, affects the number of waterbirds on the lagoon, we calculated the cumulative rainfall from 1 October to each survey date. We also compared values for cumulative precipitation within each 15-day period of each winter to ascertain that there was sufficient variability among periods that cumulative rainfall was not simply acting as a proxy for time within winter.

For estimating the effect of prior years' annual rainfall, we did not know, a priori, what the appropriate number of prior years might be for each species, but suspected that multi-year extremes in rainfall were more likely to have a measurable effect on waterbird distribution and abundance than single years of the same conditions. Since multi-year droughts were typically of 3-4 years duration, we compiled indices of rain $\left(R_{j}\right)$ for each of the previous 1-4 years of annual rainfall. We gave greater weight to the most recent years' rainfall, such that the annual rainfall index for $j$ years prior to the current year was $R_{j}=\sum r_{j} / j, j=1, \ldots$, 4, where $r_{j}$ is the total rainfall for $j$ years prior to the current year. Although the California water year starts on 1 October (www.cnrfc.noaa.gov/ rainfall_data.php, accessed 29 August 2015), we calculated annual rainfall for our study year (JuneMay) to correspond to the annual cycle most common for waterbirds on the lagoon. To test whether trends in a waterbird's population were independent of trends in rainfall, we used linear regression in program $\mathrm{R}$ (version 3.2.1, R Core Team 2014) to test for trends in annual rainfall across the entire study period (1972-2015) and during each of the two subintervals (1972-1993, 1998-2015).

We then used the R package "glm.nb" to test a candidate set of generalized linear models with a negative binomial error structure for trends in waterbird numbers relative to amounts of seasonal and past annual rainfall. The negative binomial error distribution is useful for modeling count data in which the variance is greater than the mean. True zero counts (i.e., the species is not present in the study area at the time of a survey, as opposed to present and not detected) can occur when a study site is not closed to movement in or out of the area on a survey date or within the November-February season of sampling. Because we were interested in the abundance of each species when it was present on the lagoon, but were not modeling the probability of occurrence (for which either a hurdle or zero-inflated model structure would be more appropriate), we conditioned our data on the presence of the species (zero-truncated data) and fit the models to the data so limited (Zuur et al. 2009:261-293).

The most general model took the form

$$
\ln \left(N_{i}\right) \sim \alpha_{\mathrm{i}}+\beta_{1 i} T+\beta_{2 i} T \mid P+\beta_{3 i} C+\beta_{4 i} R_{j},
$$

where for each survey, $N_{i}$ was the total individuals counted for species $i, T$ was year, $C$ was the current winter's rainfall from 1 October to the date of the survey, $R_{j}$ was a lagged index for the previous $j$ years' total rainfall, as described previously, and $P$ = 1 for year > 1997, 0 otherwise; $T, C$, and $R_{j}$ were scaled to facilitate model convergence. To account for an effect of the regional increase in habitat availability since the 1990 s on species' abundances, the third term, an interaction between $T$ and $P$, accommodated a change in trend from the 1972-1993 to the 1998-2015 period. We fit the most general model by using each of the four lagged rainfall indices $\left(R_{j}\right)$ and used the models' deviances to find the most appropriate lag period for each taxon, then compared the null (interceptonly) model to the most general model with the best-fitting $R_{j}$ with a likelihood ratio test. If that test's result suggested little support for the null model, we continued using likelihood ratio tests to eliminate nonsignificant terms from the general model for each taxon. Where $T \mid P$ but not $T$ was a significant term in the model we retained $T$; this artifact of parameterization occurred when there was no trend prior to the 1990s but either a positive or negative trend afterward.

We modified the model for a few species. We did not include rainfall terms for the Black Turnstone because, in our study area, when not on the lagoon it is restricted mostly to the rocky outer coast. Similarly, because the scoters do not typically occur inland in winter, we did not include the prior years' rainfall terms for them, though we did retain the current winter's rainfall, as storms and associated turbidity could affect their distribution by reducing the availability of their prey. Because the Canvasback was almost completely absent from the lagoon from 1998 to 2015, we modeled it only for the 1972-1993 period.

The fit and residual plots of the most general (full) models for 39 of the 42 taxa were reasonable, but for three species, the Doublecrested Cormorant, American Coot, and Western Sandpiper, the fits of the models were too poor to justify selection of a model. To understand the patterns of these three species, we modeled each of the periods separately, thus improving the models' fits and allowing us to proceed. 
We considered the pattern of a species' abundance to be consistent if its trends were positive in both periods, negative in both, or flat in both. We considered a pattern to be monotonic if the trends were consistent or if there was a trend in one period and numeric stability in the other. Because of the slowly changing bathymetry of the lagoon, reducing habitat for species that forage primarily in the subtidal zone and increasing habitat for species that forage on emerged intertidal, we divided the species into two groups based on their primary foraging habitat: (1) subtidal benthic or water column, or (2) emergent or shallowly flooded intertidal flat (Table 1). We hypothesized that, if the microhabitats available in the lagoon were determining the species' abundances, the former species should decline consistently or monotonically and the latter species increase consistently or monotonically over the period of study. From the results of the models, we compared the trend trajectories of the species in the two groups.

\section{RESULTS}

\section{RAINFAll PATTERNS}

The study encompassed several years of both extraordinarily high and low rainfall and at least three periods of multi-year drought (Figure 2A). We found no linear trend in annual rainfall over the entire 43-year study $\left(F_{1,41}=0.23, p=0.63\right)$, over the first 21 years $\left(F_{1,19}=0.65, p=0.43\right)$ or over the final 17 years $\left(F_{1,15}=0.07, p=0.80\right)$ and so found no systematic relationship between year and rainfall that might confound examination of these variables. Rainfall during the 15-day periods overlapped broadly (Figure 2B), verifying that cumulative rainfall did not closely mirror time within the winter survey period.

\section{SPECIES SUMMARY}

The median number of focal taxa per census was 40 (range 29-42). Among the 42 focal taxa using the lagoon, $26(62 \%)$ have been seen during winter moving in flocks to other nearby habitats, including the outer coast (12 taxa), sewage ponds (13 taxa), nearshore waters (6 taxa), and grazed pastures (9 taxa, Table 1). Species varied in the degree to which they moved to other habitats. For 8 species, sometimes all of the individuals on the lagoon were observed leaving to use adjacent habitats. For many species, movements between the lagoon and nearby habitats were regular and associated with tidal fluctuation. At least 29 of the 42 taxa occur regularly in flooded rice fields (Elphick and Oring 1998, Eadie et al. 2008, Strum et al.
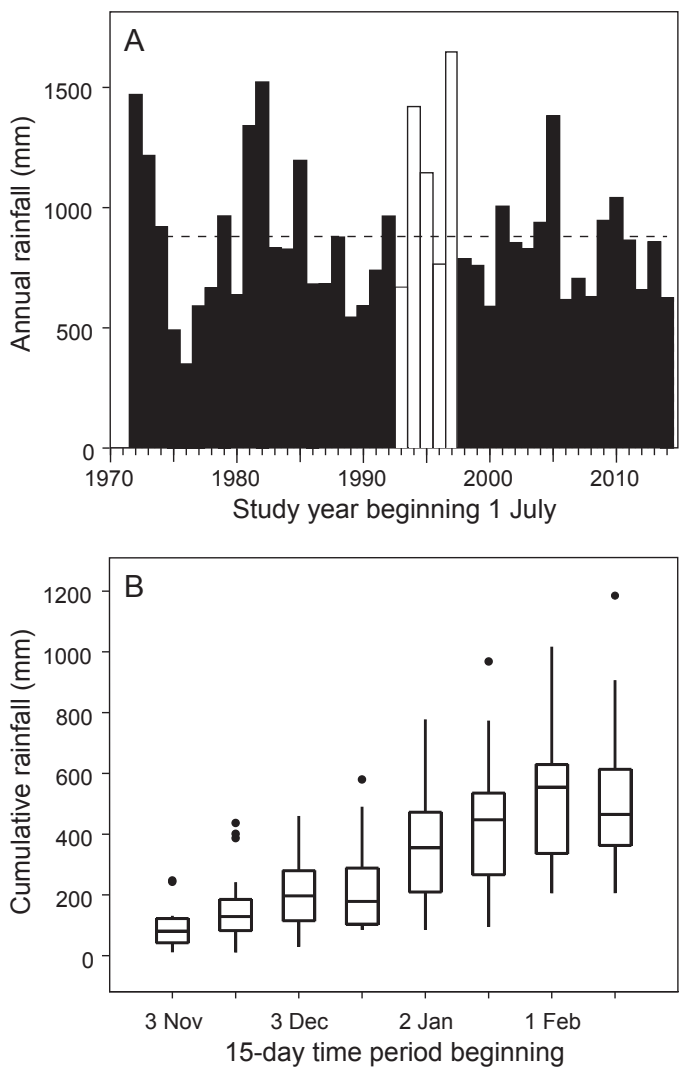

Figure 2. (A). Annual rainfall (1 June-31 May) at the Palomarin field station, Bolinas, California, from $1972-73$ to $2014-15$. Horizontal line is mean rainfall for the 43-year period. Black bars, birds surveyed that year; white bars, no surveys. The specified year refers to the first half of the annual period (e.g., 1972-73 is labeled 1972). (B). Box plots of cumulative rainfall from 1 October through dates of Bolinas Lagoon surveys between 17 November and 2 March, 1972-2015. Boxes encompass the interquartile range (25th to 75 th percentiles of data), and the horizontal line denotes the median. Vertical whiskers include data within 1.5 times the interquartile range, and outliers are indicated by dots.

2013), and all taxa analyzed for Bolinas Lagoon regularly use habitats found on the San Francisco Bay estuary (Bollman et al. 1970, Stenzel et al. 2002).

\section{EFFECTS OF PRECIPITATION}

We detected a relationship between precipitation in either the current winter or the previous 1-4 winters and the abundance of 33 taxa, including the 3 species that we modeled separately for the two periods. Among these 3 we found an effect for both periods in 1 and only for the later period in the other 2 . The current year's rainfall 
was associated with increased or decreased abundance of 19 taxa, including the Double-crested Cormorant in the later period only (Table 2). Abundances were associated with the amount of total precipitation during one or more previous years for 28 taxa, including the Western Sandpiper in the later period only (Table 2 ). We detected no effect of either the current or previous years' precipitation effect on 7 of the 41 species whose model included rainfall (Table 2).

In 14 of 19 taxa, we detected a negative relationship between the species' abundance and the current year's precipitation. The effects were similar for the two foraging groups: a negative effect of current year precipitation for 8 intertidal and 6 subtidal taxa and a positive effect for 2 intertidal and 3 subtidal taxa (Table 2). Abundance was reduced in years of higher rainfall for the American Wigeon, Northern Shoveler, Northern Pintail, Green-winged Teal, White-winged Scoter, Bufflehead, Common Goldeneye, Red-breasted Merganser, Pied-billed Grebe, Killdeer, Dunlin, Least Sandpiper, dowitcher spp., and, in the later period only, Double-crested Cormorant. Abundance was consistently elevated in years of higher rainfall for the Gadwall, scaup spp., Ruddy Duck, large grebes, and American Avocet (Table 2).

A negative association between prior years' rainfall and a species' abundance also was more frequent than a positive one (18 of 28 taxa). This negative association was more common among subtidal foragers (Canvasback, scaup spp., Bufflehead, Common Goldeneye, Red-breasted Merganser, Ruddy Duck, Horned Grebe, large grebes, Great Blue Heron, Great and Snowy egrets, Greater Yellowlegs, and Forster's Tern) than among intertidal foragers (Canada Goose, Gadwall, Eurasian Wigeon, Green-winged Teal, and American Avocet; Table 2). A positive association between prior years' rainfall and a species' abundance was more common among intertidal foragers (American Wigeon, Mallard, Northern Shoveler, Northern Pintail, American Coot, Killdeer, Willet, Western Sandpiper [1998-2015 only], and dowitcher spp.) than among subtidal foragers (only Black-crowned Night-Heron). The effect of prior years' rainfall extended back to 4 years for 12 species, 3 years for 6 species, and 1 and 2 years for 5 species each.

\section{TRENDS}

Trends in the 38 taxa for which both periods could be modeled together followed five general patterns. The trend was a monotonic increase over the entire 43 years of study for 13 taxa
(34\%), including 8 taxa for which the increase was consistent during both periods. Nine taxa (24\%) decreased monotonically, including 8 that decreased during both periods. Two taxa (5\%; Eared Grebe and Black Turnstone) had no trend across the entire study period (Table 2, Figures $3-8)$. The fourth and fifth general patterns, exemplified by 14 taxa (33\%), consisted of trends during the earlier and later periods being opposite. Among these, 12 taxa (86\%) increased during the early years, then decreased during the later years (Gadwall, Eurasian and American wigeons, Mallard, Northern Shoveler, Pied-billed Grebe, American Avocet, Black-bellied Plover, dowitchers, Greater Yellowlegs, Willet, and Forster's Tern). Only two taxa (14\%; Horned Grebe and Snowy Plover) decreased then increased.

Four species were treated separately for the two periods. The Canvasback declined significantly during the early period and was almost completely absent (and thus not modeled) after 1993 (Figure 4). Attempts to fit data for three species (American Coot, Western Sandpiper, and Doublecrested Cormorant) suggested a misspecification of our model due to discontinuity between the two periods. The cormorant exhibited no trend in either period but was more abundant in the later (Figure 5). Numbers of the American Coot declined markedly during the early period, nearly disappearing, then increased slightly during or after the gap between survey periods, and then declined subsequently (Figure 6). The Western Sandpiper increased in the early period, apparently driven by a spike in numbers in two winters, 1989-90 and 1990-91, but no trend was discernible during the late period (Figure 7).

While trends of increase were almost twice as common as decreases during the early survey period, decreases were twice as common as increases during the later years. From 1972 to 1993, the trends of 23 taxa were increases, of 12 were decreases, and 7 were flat. But from 1998 to 2015, 10 taxa increased, 21 decreased, and 10 exhibited no trend (the Canvasback excluded; Table 2).

\section{TRENDS FOR INTERTIDAL}

\section{VS. SUBTIDAL FORAGERS}

Comparing trends of species that forage primarily in intertidal habitat versus subtidal habitat was complicated by species with trajectories that changed direction between 1972-1993 and 19982015. From 1972 to 1993 , before large increases in the regional extent of wetlands, trends were increases for 15 and decreases for 5 of the species that forage primarily in transitional upland or 
TABLE 2. Summary of final models for abundance of 42 taxa of waterbirds during winter at Bolinas Lagoon, California, during two periods: 1972-1993 and 1998-2015. Data include percent of censuses on which each taxon occurred, composition of the model, the direction and significance of effects, and comparative regional trends from other sources. Model parameters are for trend $(\mathrm{T})$, change in trend after $1997(\mathrm{~T} \mid \mathrm{P})$, current winter's precipitation from 1 Oct to date of census $(\mathrm{C})$, and past $j$ years' precipitation index $\left(\mathrm{R}_{j}, j=1, \ldots 4\right.$; see Methods for calculation of indices). For simplicity, models including both terms $\mathrm{T}$ and $\mathrm{T} \mid \mathrm{P}$ are identified as $\mathrm{T} \mid \mathrm{P}$. Up arrow indicates positive coefficient or increasing trend, down arrow indicates negative coefficient or decreasing trend. Single arrows or zeros indicate $0.01<p<0.05$, double arrows or zeros indicate $0.001<p<0.01$, triple arrows or zeros indicate $p<0.001$, ns indicates $p>0.05$. Cases in which the significant interaction $(\mathrm{T} \mid \mathrm{P})$ canceled, but did not reverse, the 1972-1993 trend are indicated with zero.

\begin{tabular}{|c|c|c|c|c|c|c|c|}
\hline \multirow[b]{2}{*}{ Species } & \multirow{2}{*}{$\begin{array}{c}\% \text { of } \\
\text { censuses }\end{array}$} & \multirow[b]{2}{*}{ Model } & \multicolumn{4}{|c|}{ Direction of effects } & \multirow{2}{*}{$\begin{array}{c}\text { Other } \\
\text { sources }^{a}\end{array}$} \\
\hline & & & $\mathrm{T}$ & $\mathrm{T} \mid \mathrm{P}$ & $\mathrm{C}$ & $\mathrm{R}_{j}$ & \\
\hline Canada Goose & 41 & $\mathrm{~T}+\mathrm{R}_{4}$ & $\uparrow \uparrow \uparrow \uparrow$ & & & $\downarrow$ & $0^{2018}$ \\
\hline Gadwall & 99 & $\mathrm{~T} \mid \mathrm{P}+\mathrm{C}+\mathrm{R}_{2}$ & $\uparrow \uparrow \uparrow$ & $\downarrow \downarrow \downarrow$ & $\uparrow \uparrow \uparrow$ & $\downarrow$ & $0^{2018}$ \\
\hline Eurasian Wigeon & 72 & $\mathrm{~T} \mid \mathrm{P}+\mathrm{R}_{2}$ & $\uparrow \uparrow \uparrow$ & $\downarrow \downarrow \downarrow$ & & $\downarrow$ & \\
\hline American Wigeon & 100 & $\mathrm{~T} \mid \mathrm{P}+\mathrm{C}+\mathrm{R}_{4}$ & $\uparrow \uparrow \uparrow$ & $\downarrow \downarrow \downarrow$ & $\downarrow \downarrow \downarrow$ & $\uparrow \uparrow$ & $0^{2018}$ \\
\hline Mallard & 100 & $\mathrm{~T} \mid \mathrm{P}+\mathrm{R}_{4}$ & $\uparrow \uparrow \uparrow$ & $\downarrow \downarrow \downarrow$ & & $\uparrow \uparrow \uparrow$ & $0^{2018}$ \\
\hline Northern Shoveler & 87 & $\mathrm{~T} \mid \mathrm{P}+\mathrm{C}+\mathrm{R}_{4}$ & $\uparrow \uparrow \uparrow$ & $\downarrow \downarrow \downarrow$ & $\downarrow \downarrow \downarrow$ & $\uparrow \uparrow \uparrow$ & $\uparrow 2018$ \\
\hline Northern Pintail & 100 & $\mathrm{~T}+\mathrm{C}+\mathrm{R}_{4}$ & $\downarrow \downarrow \downarrow$ & $\downarrow \downarrow$ & $\begin{array}{l}\downarrow \downarrow \downarrow \\
\downarrow \downarrow \downarrow\end{array}$ & $\uparrow \uparrow \uparrow$ & 2018 \\
\hline Green-winged Teal & 99 & $\mathrm{~T} \mid \mathrm{P}+\mathrm{C}+\mathrm{R}_{2}$ & $\mathrm{~ns}$ & $\uparrow \uparrow \uparrow$ & $\downarrow \downarrow$ & $\downarrow \downarrow \downarrow$ & $0^{2018}$ \\
\hline Canvasback $^{b}$ & 78 & $\mathrm{~T}+\mathrm{R}_{4}$ & $\downarrow \downarrow \downarrow$ & & $\downarrow \downarrow$ & $\begin{array}{l}\downarrow \downarrow \downarrow \\
\downarrow \downarrow\end{array}$ & $\uparrow 2018$ \\
\hline Scaup spp. & 94 & $\mathrm{~T} \mid \mathrm{P}+\mathrm{C}+\mathrm{R}_{3}$ & ns & $\uparrow \uparrow \uparrow$ & $\uparrow \uparrow \uparrow$ & $\downarrow \downarrow \downarrow$ & \\
\hline Surf Scoter & 100 & $\mathrm{~T}$ & $\downarrow \downarrow \downarrow$ & & & & \\
\hline White-winged Scoter & 50 & $\mathrm{~T}+\mathrm{C}$ & $\downarrow \downarrow \downarrow$ & & $\downarrow$ & & \\
\hline Bufflehead & 100 & $\mathrm{~T} \mid \mathrm{P}+\mathrm{C}+\mathrm{R}_{4}$ & $\uparrow \uparrow$ & $\uparrow$ & $\downarrow$ & $\downarrow \downarrow \downarrow$ & $\uparrow 2018$ \\
\hline Common Goldeneye & 98 & $\mathrm{~T}+\mathrm{C}+\mathrm{R}_{1}$ & $\uparrow \uparrow$ & & $\downarrow \downarrow \downarrow$ & $\downarrow \downarrow \downarrow$ & $\uparrow 2018$ \\
\hline Red-breasted Merganser & 99 & $\mathrm{~T} \mid \mathrm{P}+\mathrm{C}+\mathrm{R}_{4}$ & $\uparrow$ & 0 & $\downarrow \downarrow$ & $\downarrow \downarrow$ & \\
\hline Ruddy Duck & 99 & $\mathrm{~T} \mid \mathrm{P}+\mathrm{C}+\mathrm{R}_{3}$ & ns & $\downarrow$ & $\uparrow \uparrow$ & $\downarrow$ & $0^{2018}$ \\
\hline Pied-billed Grebe & 85 & $\mathrm{~T} \mid \mathrm{P}+\mathrm{C}$ & $\uparrow \uparrow \uparrow$ & $\downarrow \downarrow \downarrow$ & $\downarrow$ & & $0^{2018}$ \\
\hline Horned Grebe & 100 & $\mathrm{~T} \mid \mathrm{P}+\mathrm{R}_{1}$ & $\downarrow \downarrow \downarrow$ & $\uparrow \uparrow$ & & $\downarrow \downarrow$ & \\
\hline Eared Grebe & 91 & Intercept only & ns & & & & 02018 \\
\hline Large grebes & 98 & $T+C+R_{1}$ & $\downarrow \downarrow \downarrow$ & & $\uparrow$ & $\downarrow \downarrow \downarrow$ & $0^{2013,2018}$ \\
\hline Double-crested Cormorant ${ }^{b}$ & 100 & Intercept only & ns & & & & $\uparrow^{2018}$ \\
\hline Double-crested Cormorant ${ }^{c}$ & 100 & C & ns & & $\downarrow \downarrow \downarrow$ & & \\
\hline Great Blue Heron & 100 & $\mathrm{~T} \mid \mathrm{P}+\mathrm{R}_{3}$ & $\downarrow \downarrow \downarrow$ & 00 & & $\downarrow \downarrow \downarrow$ & $\downarrow^{2018}$ \\
\hline Great Egret & 97 & $\mathrm{~T}+\mathrm{R}_{3}$ & $\uparrow \uparrow \uparrow$ & & & $\downarrow \downarrow$ & $\uparrow 2018$ \\
\hline Snowy Egret & 99 & $T \mid P+R_{3}$ & $\uparrow \uparrow \uparrow$ & 0 & & $\downarrow$ & $\uparrow 2018$ \\
\hline Black-crowned Night-Heron & 67 & $\mathrm{~T}+\mathrm{R}_{4}$ & $\downarrow \downarrow \downarrow$ & & & $\uparrow \uparrow$ & $0^{2018}$ \\
\hline American $\operatorname{Coot}^{b}$ & 91 & $\mathrm{~T}+\mathrm{R}_{4}$ & $\downarrow \downarrow \downarrow$ & & & $\uparrow \uparrow \uparrow$ & $0^{2017}$ \\
\hline American $\operatorname{Coot}^{c}$ & 65 & $\mathrm{~T}+\mathrm{R}_{4}$ & $\downarrow \downarrow \downarrow$ & & & $\uparrow \uparrow \uparrow$ & \\
\hline American Avocet & 100 & $\mathrm{~T} \mid \mathrm{P}+\mathrm{C}+\mathrm{R}_{2}$ & $\uparrow \uparrow \uparrow$ & $\downarrow \downarrow$ & $\uparrow \uparrow$ & $\downarrow \downarrow \downarrow$ & \\
\hline Black-bellied Plover & 99 & $\mathrm{~T} \mid \mathrm{P}$ & $\uparrow \uparrow$ & $\downarrow \downarrow \downarrow$ & & & \\
\hline Snowy Plover & 68 & $\mathrm{~T} \mid \mathrm{P}$ & $\downarrow \downarrow$ & $\uparrow$ & & & \\
\hline Killdeer & 68 & $\mathrm{~T}+\mathrm{C}+\mathrm{R}_{4}$ & $\downarrow \downarrow \downarrow$ & & $\downarrow \downarrow$ & $\uparrow \uparrow$ & $0^{2018}$ \\
\hline Whimbrel & 90 & $\mathrm{~T} \mid \mathrm{P}$ & $\uparrow \uparrow \uparrow$ & 000 & & & \\
\hline Long-billed Curlew & 100 & $\mathrm{~T}$ & $\uparrow \uparrow \uparrow$ & & & & $0^{2018}$ \\
\hline Marbled Godwit & 100 & $\mathrm{~T} \mid \mathrm{P}$ & $\uparrow \uparrow \uparrow$ & 000 & & & \\
\hline Black Turnstone & 79 & Intercept only & ns & & & & \\
\hline Sanderling & 94 & $\mathrm{~T} \mid \mathrm{P}$ & $\uparrow \uparrow \uparrow$ & 000 & & & \\
\hline Dunlin & 100 & $\mathrm{~T} \mid \mathrm{P}+\mathrm{C}$ & $\downarrow \downarrow \downarrow$ & $\downarrow$ & $\downarrow \downarrow \downarrow$ & & $0^{2018}$ \\
\hline Least Sandpiper & 99 & $\mathrm{~T} \mid \mathrm{P}+\mathrm{C}$ & ns & $\uparrow$ & $\downarrow \downarrow \downarrow$ & & $0^{2018}$ \\
\hline Western Sandpiper ${ }^{b}$ & 97 & $\mathrm{~T}$ & $\uparrow \uparrow \uparrow$ & & & & \\
\hline Western Sandpiper ${ }^{c}$ & 92 & $\mathrm{R}_{4}$ & ns & & & $\uparrow \uparrow \uparrow$ & \\
\hline Dowitcher spp. & 89 & $\mathrm{~T} \mid \mathrm{P}+\mathrm{C}+\mathrm{R} 1$ & $\uparrow \uparrow \uparrow$ & $\downarrow \downarrow \downarrow$ & $\downarrow \downarrow$ & $\uparrow \uparrow \uparrow$ & $0^{2018}$ \\
\hline Greater Yellowlegs & 99 & $\mathrm{~T} \mid \mathrm{P}+\mathrm{R}_{2}$ & $\uparrow \uparrow \uparrow$ & $\downarrow \downarrow \downarrow$ & & $\downarrow \downarrow$ & $\uparrow 2018$ \\
\hline Willet & 100 & $\mathrm{~T} \mid \mathrm{P}+\mathrm{R}_{1}$ & $\uparrow \uparrow \uparrow$ & $\downarrow \downarrow \downarrow$ & & $\uparrow$ & \\
\hline Forster's Tern & 85 & $\mathrm{~T} \mid \mathrm{P}+\mathrm{R}_{3}$ & $\uparrow \uparrow \uparrow$ & $\downarrow \downarrow \downarrow$ & & $\downarrow \downarrow$ & \\
\hline
\end{tabular}

${ }^{a}$ Regional trends as reported by other sources, keyed by year: Wilson et al. 2013 (covering 1975-2010), Adkins et al. 2014 (covering 1987-2010), Pandolfino and Handel 2018 (covering 1978-2014); $\downarrow$, long-term decline reported; 0, no trend detected or suspected; $\uparrow$, long-term increase reported.

${ }^{b}$ Modeled for 1972-1993 only.

cModeled for 1998-2015 only. 

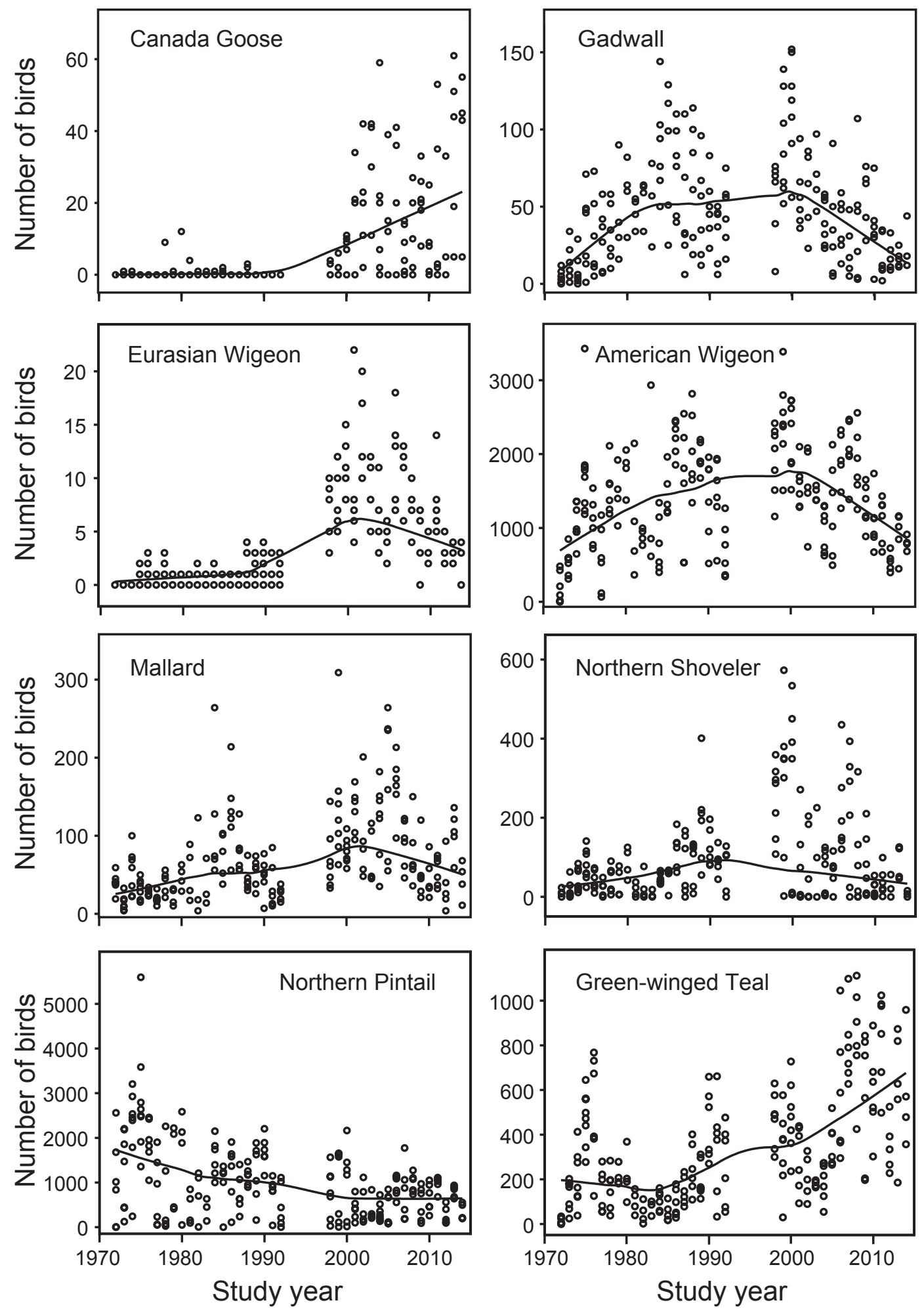

FIGURE 3. Abundance and trends of the Canada Goose and seven species of dabbling ducks as recorded on comprehensive surveys of Bolinas Lagoon, November-February, 1972-2015. Loess curves fitted to data are shown by solid lines. See Table 2 for trend assessment. 

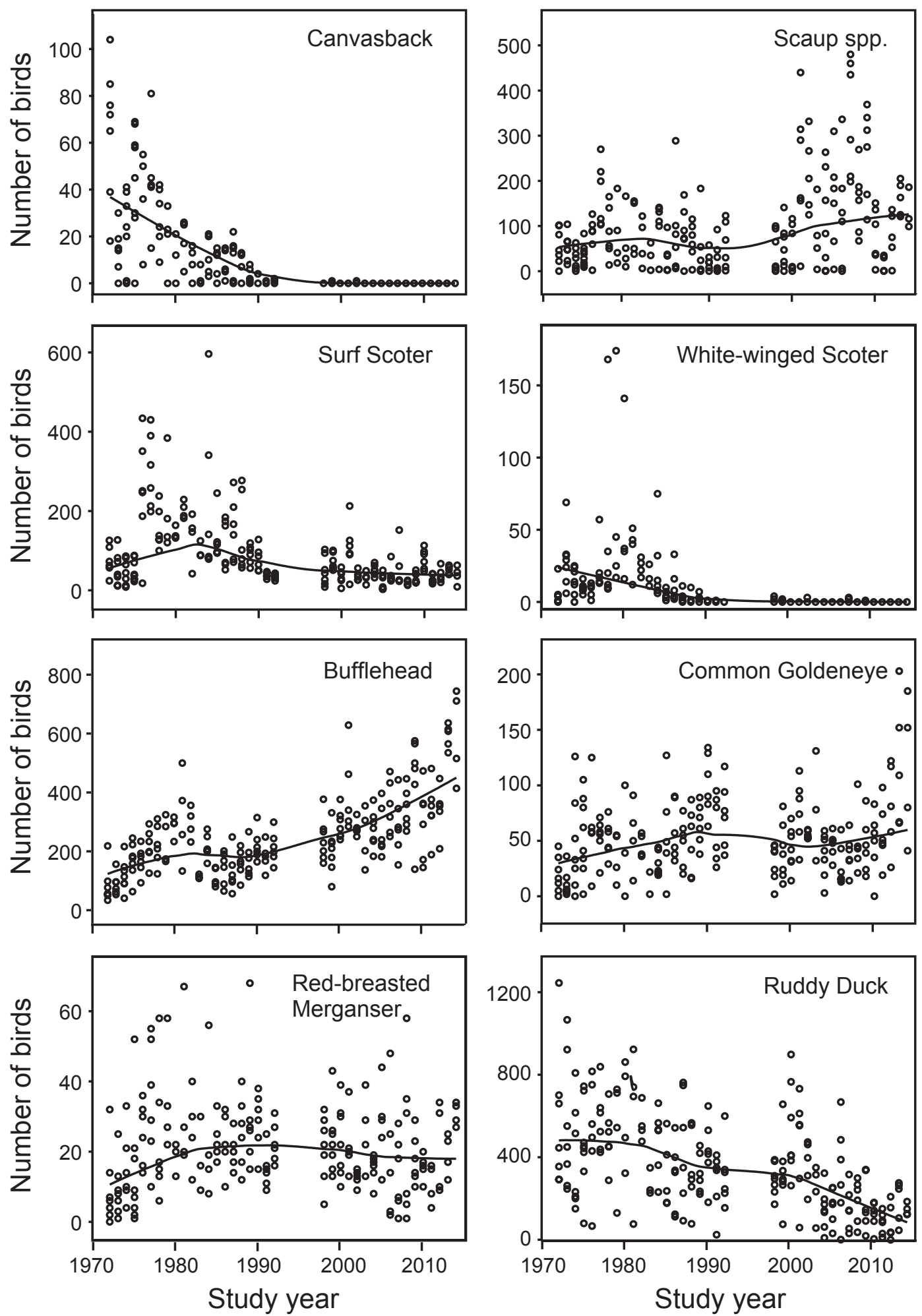

FIGURE 4. Abundance and trends of eight taxa of diving ducks as recorded on comprehensive surveys of Bolinas Lagoon, November-February, 1972-2015. Loess curves fitted to data are shown by solid lines. See Table 2 for trend assessment. Of the two scaups, the Lesser Scaup was much less common than the Greater. 

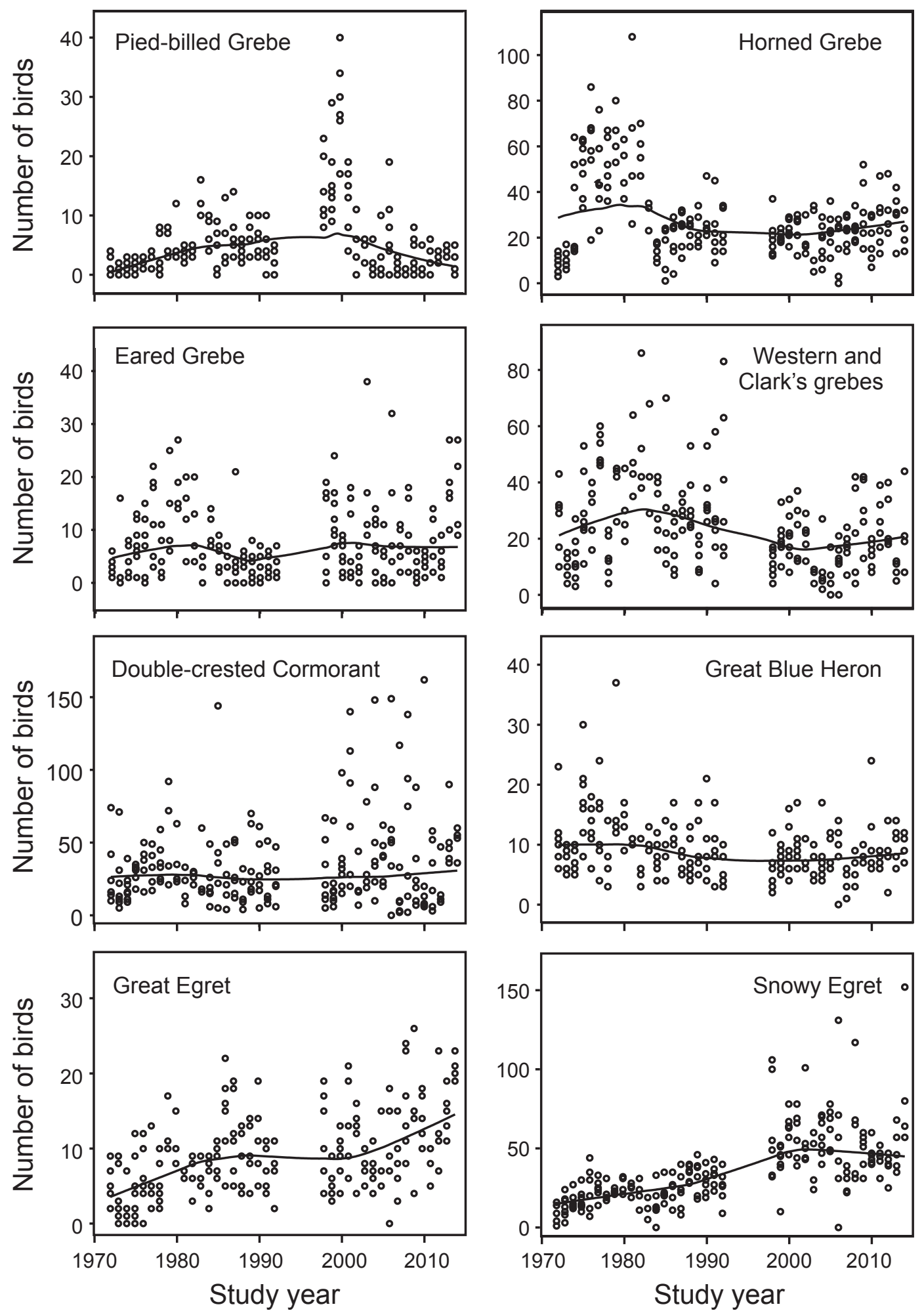

FIGURE 5. Abundance and trends of four taxa of grebes, the Double-crested Cormorant, and three species of herons as recorded on comprehensive surveys of Bolinas Lagoon, November-February, 1972-2015. Loess curves fitted to data are shown by solid lines. See Table 2 for trend assessment. Of the two species of large grebe, Clark's was much less common than the Western. 

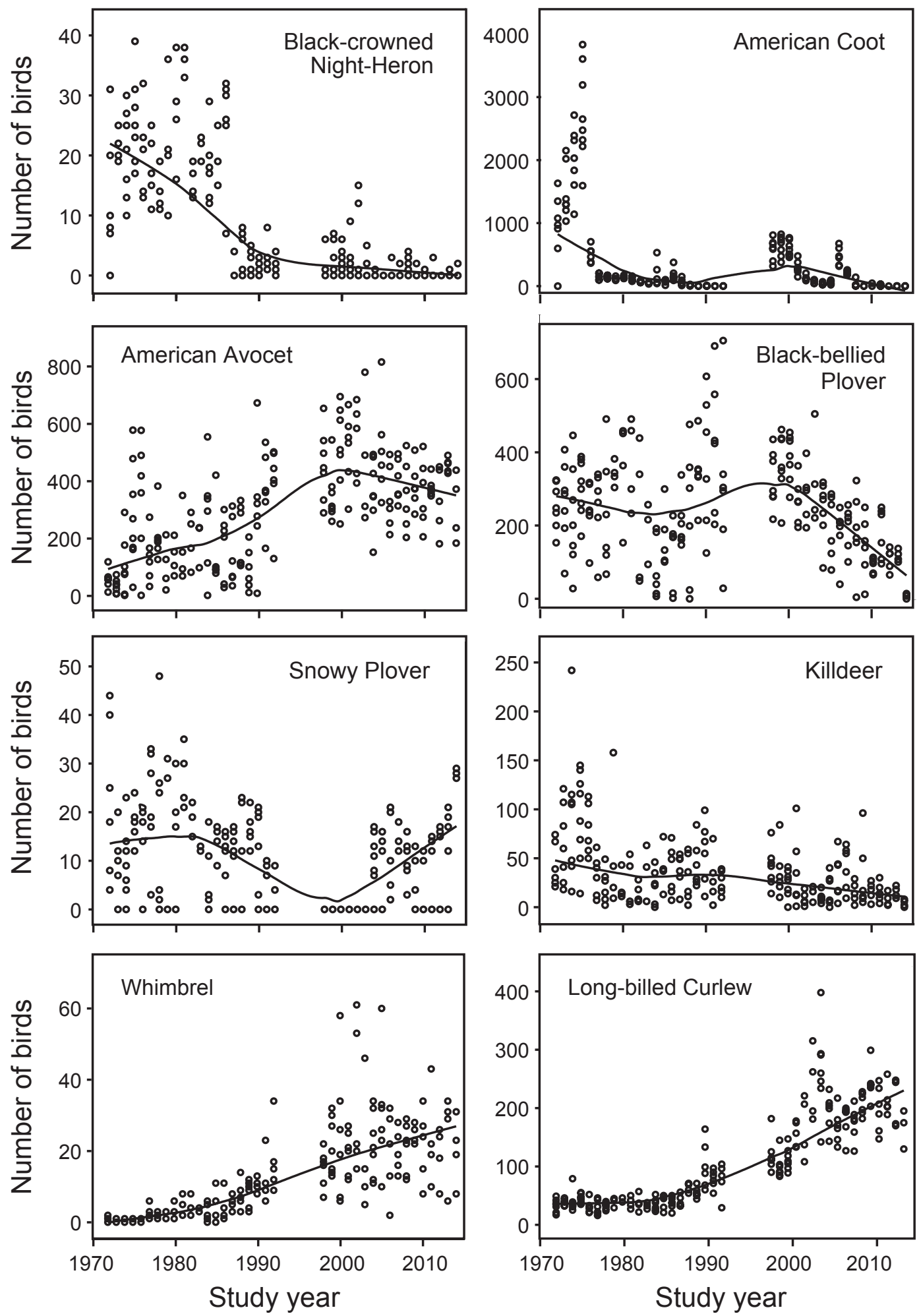

FIGURE 6. Abundance and trends of the Black-crowned Night-Heron, American Coot, and six species of shorebirds as recorded on comprehensive surveys of Bolinas Lagoon, November-February, 1972-2015. Loess curves fitted to data are shown by solid lines. See Table 2 for trend assessment. 

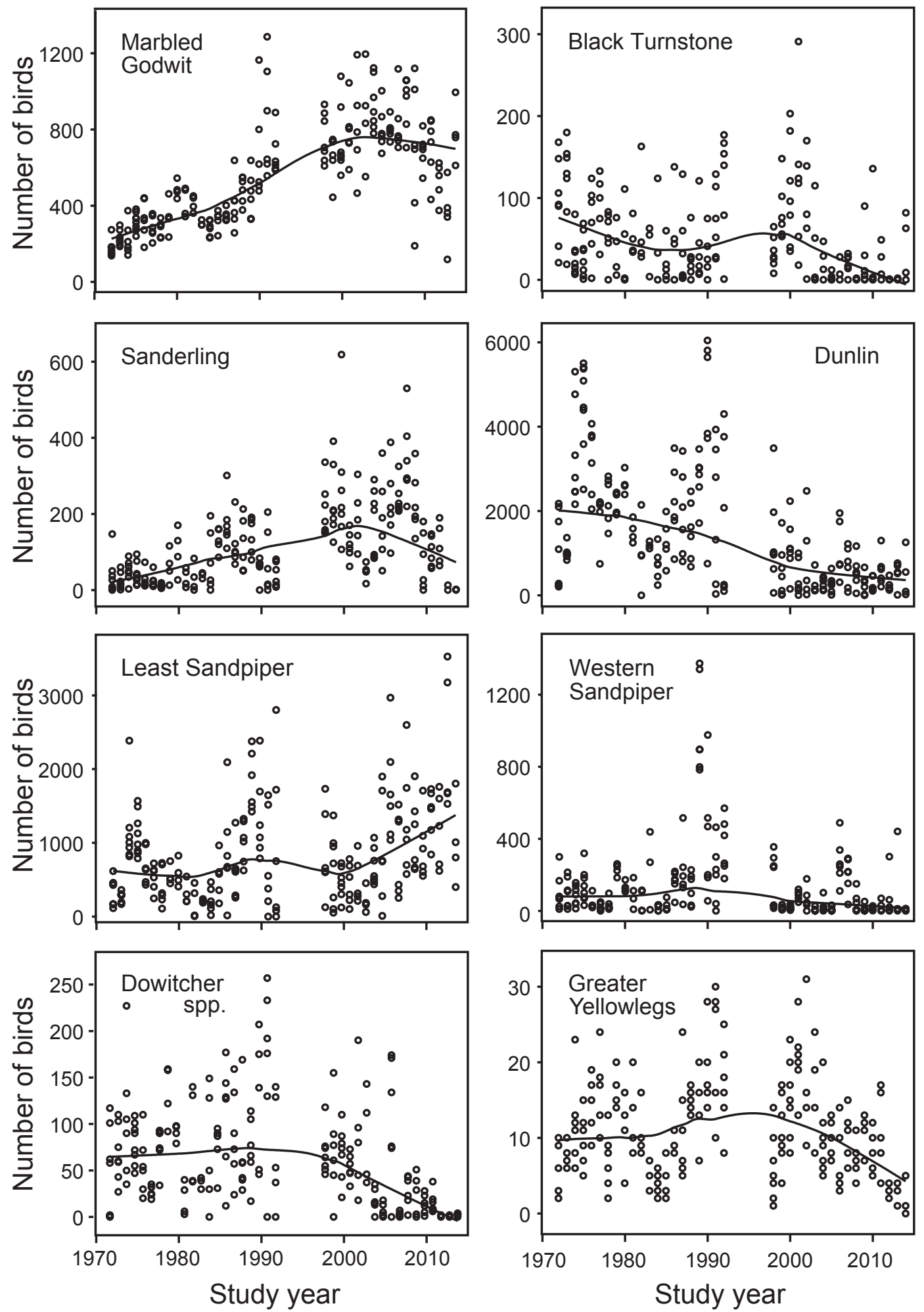

FIGURE 7. Abundance and trends of eight taxa of shorebirds recorded on comprehensive surveys of Bolinas Lagoon, November-February, 1972-2015. Loess curves fitted to data are shown by solid lines. See Table 2 for trend assessment. Of the two dowitchers, the Short-billed was very rare at Bolinas Lagoon in winter. 

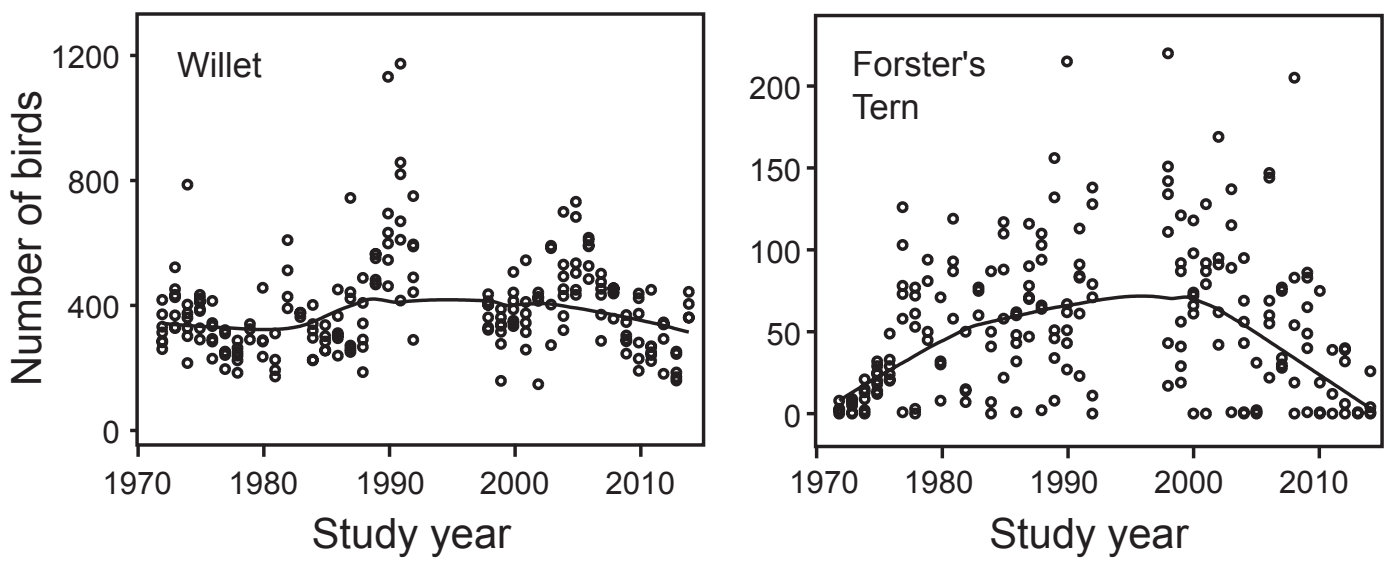

FIGURE 8. Abundance and trends of the Willet and Forster's Tern as recorded on comprehensive surveys of Bolinas Lagoon, November-February, 1972-2015. Loess curves fitted to data are shown by solid lines. See Table 2 for trend assessment.

intertidal habitat. Trends were increases for 8 and decreases for 7 of the species that forage primarily in the water column or in subtidal habitat. The difference between the two foraging groups was not significant $\left(\chi^{2}=0.95, \mathrm{df}=1, p=0.33\right.$, continuity corrected, Table 2). Likewise, from 1998 to 2015 , while wetland habitat was changing and expanding regionally, trends at the lagoon were increases for 4 and decreases for 14 of the taxa that forage primarily on emerged or intertidal habitat. During this same period trends were increases for 5 and decreases for 7 of the taxa that forage primarily in the water column or in subtidal habitat ( $p=0.42$, two-sided Fisher exact test).

\section{Possible Distributional \\ SHIFTS TO RICE FIELDS}

Among the lagoon's 22 taxa that commonly use rice fields flooded after harvest (Table 1), the patterns of 12 were consistent with a possible distributional shift away from Bolinas Lagoon in the later years of our study. The patterns of 6 were inconsistent with such a shift, and those of 4 were neither consistent nor inconsistent (Table 2, Figures 3-8). Taxa with patterns consistent with a possible distributional shift to regional rice fields included 10 that had been increasing in the lagoon during the early period but declined during the later period (Gadwall, Eurasian and American wigeons, Mallard, Northern Shoveler, Pied-billed Grebe, American Avocet, Black-bellied Plover, Greater Yellowlegs, and dowitchers), one that had been decreasing in the lagoon in the early period and then decreased at a faster rate in the later period (Dunlin), and one that had been increasing in the lagoon during the early period and then stabilized during the later years (Snowy Egret). Taxa with trends inconsistent with such a distributional shift included three that increased at the same rate in both periods (Canada Goose, Great Egret, and Long-billed Curlew), one that had declined in the early period then was stable in the later (Great Blue Heron), and two that had been stable in the early period then increased in the later (Green-winged Teal and Least Sandpiper). The remaining four taxa showed no pronounced change in trend between the two periods (Northern Pintail, Black-crowned NightHeron, American Coot, and Killdeer).

\section{DISCUSSION}

Among 42 taxa of waterbirds wintering at Bolinas Lagoon, abundances of 40 were significantly related to year, amount of precipitation, or both factors. Difference in trends between the early (1972-1993) and later (1998-2015) census periods appeared to be related to regional changes in habitat and possible distributional shifts. In our models, for most species using the lagoon, inclusion of the amount of precipitation during the current winter or during past years enhanced our ability to detect trends in abundance. Inclusion of precipitation variables could make analyses at other sites where rainfall is an important ecological determinant of distribution more sensitive to underlying trends in abundance.

\section{EFFECTS OF Precipitation}

The significance of terms for the current winter's and previous years' rainfall in our models suggests that precipitation is particularly important in determining a species abundance at Bolinas 
Lagoon. We and others previously detected the importance of the current year's winter rainfall for some species at Bolinas Lagoon or other coastal wetlands (Page et al. 1979, Shuford et al. 1989, Warnock et al. 1995, Kelly 2001, Canepuccia et al. 2007, Aarif et al. 2014). Because winter storms in central California are characterized by rain, wind, and low barometric pressure (Kelly et al. 2002), and years of low storm intensity are sometimes associated with periods of lower than normal temperatures (to below freezing), we recognize that factors correlated with rainfall also may contribute to the apparently significant effect of rainfall on waterbird numbers at this coastal estuary.

Our analyses and those of Aarif et al. (2014) suggest that the abundance of waterbirds is related to past years' rainfall. Past years' rainfall may influence not only the regional distribution of wet habitat in early winter but also the abundance and distribution of fish prey (Meynecke et al. 2006). The relationship may thus reflect indirect effects on overwinter survival of some waterbird species. Although increased rainfall could benefit the winter population of some species, an increase in the extent of habitat could reduce the numbers wintering at a given site if, overall, birds spread out among more sites. In agreement with this hypothesis, at Bolinas Lagoon we found a negative relationship between prior years' rainfall and a species' abundance to be almost twice as common as a positive relationship; a negative relationship with the current winter's rainfall was almost three times as common as a positive one. Likewise, Aarif et al. (2014) noted negative associations between numbers of shorebirds and both current and prior year's rainfall at a coastal wetland in India.

\section{TRENDS}

We discovered significant trends in the abundance of 39 of 42 waterbird taxa during one (12 taxa, $29 \%$ ) or both (27 taxa, 64\%) periods of our study. Linking trends to their causes is complex. Trends in abundance at a given site are a function of the regional population size, suitability of the site, and the extent and quality of alternative regional habitats. When these factors are changing simultaneously over time, the influence of one may outweigh others. This may be particularly true in years that regional habitat is close to carrying capacity. And, while trends at individual sites are often of great local interest, understanding which demographic rates are driving regional trends is of great general interest.

Regional trends affect species' trajectories at the scale of a site (Wilson et al. 2013, Adkins et al. 2014, Fleskes et al. 2018). Pandolfino and Handel (2018) estimated population trajectories in the Central Valley for 26 taxa considered in our study on the basis of Christmas Bird Count data. They found 8 of these increasing, 16 stable, and 2 decreasing (Table 2). For 8 of those 26 taxa (23\%), trends for the Central Valley are consistent with study-long trends at Bolinas Lagoon (Table 2). These include increases of the Bufflehead, Common Goldeneye, Double-crested Cormorant, Great Egret, and Snowy Egret, stable numbers of the Eared Grebe, and declines of the Northern Pintail and Great Blue Heron (Figures 3-8, Table 2 ). While we expected regional trends to have a strong influence on an individual site, trends at Bolinas Lagoon were similar to those for the Central Valley for fewer than a quarter of the taxa.

Resources at Bolinas Lagoon have clearly changed over the study, particularly those associated with changes in the extent of subtidal (decreasing), intertidal (increasing), and vegetated marsh (increasing) habitats (MCOSD 2006). Nonetheless, we did not find a preponderance of declines among species that forage in subtidal habitats or a preponderance of increases among those that forage in intertidal habitats, as would be predicted by the lagoon's changing bathymetry. Regional population trends may have obscured the effects of local habitat changes for some species, because all five species increasing both in the Central Valley and at Bolinas Lagoon are subtidal foragers.

\section{Possible Distributional SHIFTS TO RICE FIELDS}

As previously described, wetlands became much more extensive in central California after the mid-1990s than they had been previously. The change in the means of decomposing rice straw substantially increased the extent of shallowly flooded fields in the northern Central Valley. Fleskes et al. (2018) reported major regional shifts in the abundance of waterfowl within the Central Valley coinciding with this change in treatment of rice after harvest. We hypothesize that this change may also have affected waterbirds' abundances at Bolinas Lagoon. If birds shifted from the coast to the interior in response to this major increase in potential habitat, trends on Bolinas Lagoon might provide supporting evidence. Among 22 taxa using the lagoon that also commonly use flooded rice fields, trends of 12 were consistent with such a distributional shift, while 6 were not (trend patterns of 4 were neutral). These results suggest some support for the hypothesis that increased 
habitat in central California may have drawn birds from Bolinas Lagoon.

If some waterbird species shifted to inland habitat in response to flooding of harvested rice fields, two processes may have been operating, possibly concurrently. First, immature birds, with no prior fidelity to a winter site, may have been more attracted to the expansive flooded habitats newly available inland than to coastal lagoons. Populations along the coast would decline over time without sufficient recruitment of young to replace the site-faithful adults lost to mortality. Second, species that are typically faithful to coastal sites have been observed in the interior after fleeing adverse conditions during major storms. Some of these individuals may have changed their winter site fidelity, particularly if they experienced sufficient or better foraging and/or a lower risk of predation elsewhere than at Bolinas Lagoon. Other factors may also have driven range shifts, such as changes in prey availability, as has been suggested for Aechmophorus grebes (Wilson et al. 2013), or climate change, as has been suggested for shorebirds (Maclean et al. 2008).

Interspecific interactions may also have played a role in distributional shifts of some species at Bolinas Lagoon. Avian predators, particularly falcons, were present throughout our study (Point Blue unpubl. data) and, on California Christmas Bird Counts, the numbers of both the Peregrine Falcon (Falco peregrinus) and Merlin (F. columbarius) increased substantially over the 43 years of our study (National Audubon Society 2016). These predators are responsible for substantial levels of winter shorebird mortality at Bolinas Lagoon and other estuaries (Page and Whitacre 1975, Kus et al. 1984, Cresswell and Whitfield 1994), and there is compelling evidence that risk of predation influences shorebirds' behavior and distribution, particularly where proximate cover for predators is near tidal flats, such as at small coastal estuaries (Ydenberg et al. 2002, 2004, 2017, Lank et al. $2003,2017)$. Thus a high risk of predation may have been an added stimulus for waterbirds to disperse from Bolinas Lagoon if alternative habitat was available.

\section{THE FUTURE FOR WATERBIRDS ON BOLINAS LAGOON}

Anticipated and unexpected changes in the extent of subtidal, unvegetated intertidal, and vegetated marsh habitat at Bolinas Lagoon (and other wetlands in central California) may become important drivers of abundance of waterbirds in the future. Several aspects of climate change, major seismic events, and major human alteration of the landscape are the most obvious examples of such factors.

Accelerating sea-level rise is an anticipated component of climate change, but the rate of acceleration is still highly uncertain, high and low estimates for the next century differing by a factor of 3 (Takekawa et al. 2013). Sea-level rise was projected to start outpacing sediment accretion at Bolinas Lagoon about the time our study ended (MCOSD 2006, Brennan 2017), as it has in recent decades around San Francisco Bay (Takekawa et al. 2013). Projections for California's precipitation are highly uncertain, but longer droughts interspersed with occasional exceptionally wet winters are anticipated to be more common (Diffenbaugh et al. 2015, CDWR 2015). Increasing temperature, sea-level rise, and a possible increased frequency of strong storms will affect coastal wetlands through flooding of low-lying areas, intensifying evaporation and desiccation of some areas, changing local hydrology, increasing coastal erosion, and increasing fires in the watershed, leading to more erosion (Godet et al. 2011, Takekawa et al. 2013, Diffenbaugh et al. 2015, CDWR 2015). Changes in precipitation and temperature will affect the availability of water to agricultural users, wildlife refuges, and a growing urban population, intensifying competition among them (Fleskes et al. 2018). Flooding rice fields or growing rice at all may cease to be viable.

Seismic and human activities hold even more uncertainty. A large earthquake along the San Andreas Fault, such as that of 1906, should affect the availability of both habitat and prey and should increase the lagoon's tidal prism (Emmett et al. 2000, MCOSD 2006). Another important source of uncertainty is how the human response to climate-related changes may affect the changing extent of wetlands, both coastal and inland. Will barriers (coastal armoring) be constructed in response to changing hydrology and rising seas? Might we see additional changes in choices of agricultural crops or practices after harvest in nearby inland habitats? Such uncertainties complicate predictions of the future abundance of waterbirds at Bolinas Lagoon, but our results suggest that future use of the lagoon will be sensitive to changes in both climate and the landscape.

\section{BOLINAS LAGOON AND LARGE-SCALE MONITORING PROJECTS}

While the trajectories of the populations of wideranging birds must be measured over broad geographic regions, large-scale monitoring programs must be assembled site by site (e.g., the 
Mid-winter Waterfowl Survey of the U.S. Fish and Wildlife Service, the Canada-U.S. Program for Regional and International Shorebird Monitoring [PRISM], and Point Blue Conservation Science's Pacific Flyway Shorebird Survey Project). It is therefore important that the factors, including physical processes and biological relationships, responsible for variability in abundance at individual sites be understood (Norris et al. 2004). We found the effects of the current or past years' precipitation to be sufficiently large that our models could not achieve acceptable fits or identify trends for most species without accounting for rainfall. Large-scale projects monitoring populations may be able to increase their ability to detect trends in numbers by including informative covariates, such as climate variables, in their models, particularly in arid regions. Furthermore, sites selected for monitoring are often those that are considered important at the commencement of the study, but as our results for the Canvasback, Ruddy Duck, Long-billed Curlew, and Dunlin at Bolinas Lagoon show, their relative importance for some species may change considerably over time. It would be valuable to understand the process by which waterbirds are recruited into newly created habitat or shift their distribution away from traditionally occupied sites. Further study with marked and radio-tagged birds would be informative, as would a comparison of age ratios of birds captured at newly created sites with those at nearby established wetlands. Such studies would also illuminate aspects of sites' connectivity, important to the conservation of migratory species (Warnock 2010, Iwamura et al. 2013). Understanding these processes at both the large and local scales will greatly enhance our understanding of how and why abundances of waterbirds are changing across the landscape and thereby increase the effectiveness of conservation measures.

\section{ACKNOWLEDGMENTS}

This study started through a generous donation from the Marin Audubon Society and a grant from the county of Marin in 1972. It would not have been possible without the substantial contribution of time and expertise by volunteers, interns, and staff of Point Blue Conservation Science. Figure 1 was generously provided by J. Howar. Many observers participated in multiple years of censuses, including P. Ashman, F. Cox, W. Eastman, J. Evens, P. Faber, M. Forney, C. Hickey, K. Howard, S. N. G. Howell, B. Kus, J. Lamphier, M. Mayer, R. Mayer, L. Prairie, H. Pratt, P.
Pyle, A. Rovetta, W. D. Shuford, R. Stewart, N. Warnock, and A. Williams. Staff and interns at Point Blue's Palomarin field station faithfully collected and vetted decades of weather data, which they generously shared. K. Hansen, S. N. G. Howell, P. R. Pyle, and N. Warnock shared their knowledge of local movements of the waterbirds on the lagoon, and discussions with D. G. Ainley, and P. R. Pyle greatly increased our knowledge of the regional distribution and potential prey of species feeding near shore. B. Huning of the San Francisco Bay Joint Venture provided up-to-date information on regional efforts at restoration since the 1990s. Christmas Bird Count data for the falcons were provided by the National Audubon Society and through the generous efforts of Bird Studies Canada and countless volunteers across the western hemisphere. The advice of M. Reiter and L. Salas on analyses was indispensable. R. Gill, C. Handel, S. N. G. Howell, P. Pyle, M. Reiter, W. D. Shuford, N. Seavy, N. Warnock, and an anonymous reviewer greatly improved the manuscript with their suggestions and comments. This is contribution number 2137 of Point Blue Conservation Science.

\section{Literature Cited}

Aarif, K. M., Muzaffar, S. B., Babu, S., and Prasadan, P. K. 2014. Shorebird assemblages respond to anthropogenic stress by altering habitat use in a wetland in India. Biodiversity Conserv. 23:727-740; doi 10.1007/s10531-014-0630-9.

Adkins, J. Y., Roby, D. D., Lyons, D. E., Courtot, K. N., Collis, K., Carter, H. R., Shuford, W. D., and Capitolo, P. J. 2014. Recent population size, trends, and limiting factors for the Double-crested Cormorant in western North America. J. Wildl. Mgmt. 78:1131-1142; doi 10.1002/jwmg.737.

Anderson, W. 1970. A preliminary study of the relationship of saltponds and wildlife-South San Francisco Bay. Calif. Fish Game 56:240-252.

Athearn, N. D., Takekawa, J. Y., and Shinn, J. M. 2009. Avian response to early tidal salt marsh restoration at former commercial salt evaporation ponds in San Francisco Bay, California, USA. Nat. Resour. Environ. Issues 15: article 14; digitalcommons.usu.edu/ nrei/vol15/iss $1 / 14$.

Attrill, M. J., Rundle, S. D., and Thomas, R. M. 1996. The influence of drought-induced low freshwater flow on an upper-estuarine macroinvertebrate community. Water Resour. 30:261-268; doi 10.1016/0043-1354985000186-7.

Austin, G. E., and Rehfisch, M. M. 2005. Shifting nonbreeding distributions of migratory fauna in relation to climate change. Global Change Biol. 11:31-38; doi 10.1111/j.1529-8817.2003.00876.x. 
Bollman, F. H., Thelin, P. K., and Forester, R. T. 1970. Bimonthly bird counts at selected observation points around San Francisco Bay, February 1964 to January 1966. Calif. Fish Game 56:224-239.

Brennan, M. 2017. Bolinas Lagoon bathymetry reassessment. ESA, PWA report to the County of Marin; www.marincountyparks.org/ /media/files/ departments/pk/about-us/agendas-minutes/2017/ blac/bolinasbathy--blac-mtg-20170428.pdf?la=en.

CaliforniaDepartmentofWaterResources(CDWR).2015. California climate science and data for water resource management; www.water.ca.gov/climatechange/docs/ CA_Climate_Science_and_Data_Final_Release_ June_2015.pdf.

California Rice Commission. 2012. Environmental sustainability report. Report prepared by Summers Consulting, LLC; calrice.org/pdf/Sustainability+Report.pdf.

Canepuccia, A. D., Isacch, J. P., Gagliardini, D. A., Escalante, A. H., and Iribarne, O. O. 2007. Waterbird response to changes in habitat area and diversity generated by rainfall in a SW Atlantic coastal lagoon. Waterbirds 30:541-553; doi 10.1675/1524-4695(2007)030[0541:WRTCIH]2. $0 . \mathrm{CO} ; 2$.

Colwell, M. A. 1994. Shorebirds of Humboldt Bay, California: Abundance estimates and conservation implications. W. Birds 25:137-145.

Cresswell, W., and Whitfield, D. P. 1994. The effects of raptor predation on wintering wader populations at the Tyningharne estuary, southeast Scotland. Ibis 136:223-232; doi 10.1111/j.1474-919x.1994. tb01088.x.

Diffenbaugh, N. S., Swain, D. L., and Touma, D. 2015. Anthropogenic warming has increased drought risk in California. Proc. Natl. Acad. Sci. USA 112:39313936; doi 10.1073/pnas.1422385112.

Drinkwater, K. F., and Frank, K. T. 1994. Effect of river regulation and diversion on marine fish and invertebrates. Aquat. Conserv.: Freshwater Mar. Ecosyst. 4:135-151; doi 10.1002/aqc.3270040205.

Eadie, J. M., Elphick, C. S., Reinecke, K. J., and Miller, M. R. 2008. Wildlife values of North American ricelands, in Conservation in Ricelands of North America (W. W. Manley, ed.), pp. 7-90. The Rice Foundation, Stuttgart, AR.

Elphick, C. S., and Oring, L. W. 1998. Winter management of California rice fields for waterbirds. J. Appl. Ecol. 35:95-108; doi 10.1046/j.13652664.1998.00274.x.

Emmett, R., Llansó, R., Newton, J., Thom, R., Hornberger, M., Morgan, C., Levings, C., Copping, A., and Fishman, P. 2000. Geographic signatures of North American west coast estuaries. Estuaries 23:765-792; doi 10.2307/1352998.

Fleskes, J. P., Jarvis, R. L., and Gilmer, D. S. 2002. Distribution and movements of female Northern Pintail radiotagged in San Joaquin Valley, California. J. Wildl. Mgmt. 66:138-152; doi 10.2307/3802880.

Fleskes, J. P., Perry, W. M., Petrik, K. L., Spell, R., and
Reid, F. 2005. Change in area of winter-flooded and dry rice in the northern Central Valley of California determined by satellite imagery. Calif. Fish Game 91:207-215.

Fleskes, J. P., Casazza, M. L., Overton, C. T., Matchett, E. L., and Yee, J. L. 2018. Changes in the abundance and distribution of waterfowl wintering in the Central Valley of California, 1973-2000, in Trends and traditions: Avifaunal change in western North America (W. D. Shuford, R. E. Gill Jr., and C. M. Handel, eds.), pp. 50-74. Studies of Western Birds No. 3. Western Field Ornithologists, Camarillo, CA; doi 10.21199/SWB3.2.

Godet, L., Jaffré, M., and Devictor, V. 2011. Waders in winter: Long-term changes of migratory bird assemblages facing climate change. Biol. Lett. 7:714-717; doi 10.1098/rsbl.2011.0152.

Henkel, L. A. 2006. Effect of water clarity on the distribution of marine birds in nearshore waters of Monterey Bay, California. J. Field Ornithol. 77:151-156; doi 10.1111/j.1557-9263.2006.00035.x.

Iwamura, T., Possingham, H. P., Chadès, I., Minton, C., Murray, N. J., Rogers, D. I., Treml, E. A., and Fuller, R. A. 2013. Migratory connectivity magnifies the consequences of habitat loss from sea-level rise for shorebird populations. Proc. R. Soc. B 280:20130325; doi 10.1098/rspb.2013.0325.

Kelly, J. P. 2001. Hydrographic correlates of winter Dunlin abundance and distribution in a temperate estuary. Waterbirds 24:309-322; doi 10.2307/1522061.

Kelly, J. P., and Condeso, T. E. 2017. Tidal marsh restoration stimulates the growth of winter shorebird populations in a temperate estuary. Restor. Ecol. 25:640-649; doi 10.1111/rec.12487.

Kelly, J. P., and Tappen, S. L. 1998. Distribution, abundance, and implications for conservation of winter waterbirds on Tomales Bay, California. W. Birds 29:103-120.

Kelly, J. P., Warnock, N., Page, G. W., and Weathers, W. W. 2002. Effects of weather on daily body mass regulation in wintering Dunlin. J. Exp. Biol. 205:109-120.

Kimmerer, W. J. 2002. Effects of freshwater flow on abundance of estuarine organisms: Physical effects or trophic linkages? Mar. Ecol. Prog. Ser. 243:39-55; doi 10.3354/meps243039.

Kus, B. E., Ashman, P., Page, G. W., and Stenzel, L. E. 1984. Age-related mortality in a wintering population of Dunlin. Auk 101:69-73.

Lank, D. B., Butler, R. W., Ireland, J., and Ydenberg, R. C. 2003. Effects of predation danger on migration strategies of sandpipers. Oikos 103:303-319; doi 10.1034/j.1600-0706.2003.12314.x.

Lank, D. B., Xu, C., Harrington, B. A., Morrison, R. I. G., Gratto-Trevor, C. L., Hicklin, P. W., Sandercock, B. K., Smith, P. A., et al. 2017. Long-term continental changes in wing length, but not bill length, of a long-distance migratory shorebird. Ecol. Evol. 7:3243-3256; doi 10.1002/ece3.2898.

Maclean, I. M. D., Austin, G. E., Rehfisch, M. M., Blew, J., Crowe, O., Delany, S., Devos, K., Deceun- 
inck, B., et al. 2008. Climate change causes rapid changes in the distribution and site abundance of birds in winter. Global Change Biol. 14:2489-2500; doi 10.1111/j.1365-2486.2008.01666.x.

Marin County Open Space District (MCOSD). 2006. Bolinas Lagoon ecosystem restoration project. Report prepared for Marin County Open Space District, 3501 Civic Center Drive, San Rafael, CA 94903; www.marincounty.org/ /media/files/departments/ $\mathrm{pk} /$ projects/open-space/bolinas-lagoon/executivesummary.pdf

Meynecke, J. O., Lee, S. Y., Duke, N. C., and Warnken, J. 2006. Effect of rainfall as a component of climate change on estuarine fish production in Queensland, Australia. Estuarine, Coastal Shelf Sci. 69:491-504; doi 10.1016/j.ecss.2006.05.011.

Moore, J. E., and Black, J. M. 2006. Historical changes in Black Brant Branta bernicla nigricans use on Humboldt Bay, California. Wildl. Biol. 12:151-162; doi 10.2981/0909-6396(2006)12[151:HCIBBB]2.0. $\mathrm{CO} ; 2$.

Moyle, P. B. 1995. Conservation of native freshwater fishes in the Mediterranean-type climate of California, USA: A review. Biol. Conserv. 72:271-279; doi 10.1016/0006-3207(94)00089-9.

Musil, P., Musilová, Z., Fuchs, R., and Poláková, S. 2011. Long-term changes in numbers and distribution of wintering waterbirds in the Czech Republic, 1966-2008. Bird Study 58:450-460; doi 10.1080/00063657.2011.603289.

National Audubon Society. 2016. The Christmas Bird Count historical results [online]; www.christmas birdcount.org (accessed 15 January 2018).

Nichols, F. H. 1985. Increased benthic grazing: An alternative explanation for low phytoplankton biomass in northern San Francisco Bay. Estuarine, Coastal Shelf Sci. 21:379-388; doi 10.1016/02727714(85)90018-6.

Norris, K., Atkinson, P. W., and Gill, J. A. 2004. Climate change and coastal waterbird populationspast declines and future impacts. Ibis 146 (Suppl. 1): 82-89; doi 10.1111/j.1474-919X.2004.00331.x.

Page, G., and Whitacre, D. F. 1975. Raptor predation on wintering shorebirds. Condor 77:73-83.

Page, G. W., Stenzel, L. E., and Wolfe, C. M. 1979. Aspects of the occurrence of shorebirds on a central California estuary. Studies Avian Biol. 2:15-32.

Page, G. W., Stenzel, L. E., and Kjelmyr, J. E. 1999. Overview of shorebird abundance and distribution in wetlands of the Pacific coast of the contiguous United States. Condor 101:461-471.

Pandolfino, E. R., and Handel, C. M. 2018. Population trends of birds wintering in the Central Valley of California, in Trends and traditions: Avifaunal change in western North America (W. D. Shuford, R. E. Gill Jr., and C. M. Handel, eds.), pp. 215-235. Studies of Western Birds No. 3. Western Field Ornithologists, Camarillo, CA; doi 10.21199/SWB3.12.

R Core Team. 2014. R: A language and environment for statistical computing. R Foundation for Statistical Computing, Vienna, Austria; www.R-project.org/.

Robertson, G. J., and Cooke, F. 1999. Winter philopatry in migratory waterfowl. Auk 116:20-34; doi $10.2307 / 4089450$.

Sanzenbacher, P. M., and Haig, S. M. 2002. Residency and movement patterns of wintering Dunlin in the Willamette Valley of Oregon. Condor 104:271280; doi: 10.1650/0010-5422(2002)104[0271:RA MPOW]2.0.CO;2.

Shuford, W. D., Page, G. W., Evens, J. G., and Stenzel, L. E. 1989. Seasonal abundance of waterbirds at Point Reyes: A coastal California perspective. W. Birds 20:137-265.

Stenzel, L. E., Huber, H. R., and Page, G. W. 1976. Feeding behavior and diet of the Long-billed Curlew and Willet. Wilson Bull. 88:314-332.

Stenzel, L. E., Hickey, C. M., Kjelmyr, J. E., and Page, G. W. 2002. Abundance and distribution of shorebirds in the San Francisco Bay area. W. Birds 33:69-98.

Strum, K. M., Reiter M. E., Hartman C. A., Iglecia, M. N., Kelsey, T. R., and Hickey, C. M. 2013. Winter management of California's rice fields to maximize waterbird habitat and minimize water use. Agric. Ecosyst. Environ. 179:116-124; doi 10.1016/j. agee.2013.08.003.

Takekawa, J. Y., Lu, C. T., and Pratt, R. T. 2001. Avian communities in baylands and artificial salt evaporation ponds of the San Francisco Bay estuary. Hydrobiologia 455:317-328.

Takekawa, J. Y., Warnock, N., Martinelli, G. M., Miles, A. K., and Tsao, D. C. 2002. Waterbird use of bayland wetlands in the San Francisco Bay estuary: Movements of Long-billed Dowitchers during the winter. Waterbirds 25 (Spec. Publ. 2): 93-105.

Takekawa, J. Y., Thorne, K. M., Buffington, K. J., Spragens, K. A., Swanson, K. M., Drexler, J. Z., Schoellhamer, D. H., Overton, C. T., and Casazza, M. L. 2013. Final report for sea-level rise response modeling for San Francisco Bay estuary tidal marshes. U.S. Geological Survey Open File Rep. 2012-1081; pubs. usgs.gov/of/2013/1081/pdf/ofr20131081.pdf.

Warnock, N. 2010. Stopping vs. staging: The difference between a hop and a jump. J. Avian Biology 41:621626; doi 10.1111/j.1600-048X.2010.05155.x.

Warnock, N., Page, G. W., and Stenzel, L. E. 1995. Nonmigratory movement of Dunlins on their California wintering grounds. Wilson Bull. 107:131-139.

Warnock, N., Page, G. W., and Sandercock, B. K. 1997. Local survival of Dunlin wintering in California. Condor 99:906-915; doi 10.2307/1370141.

Warnock, N., Page, G. W., Ruhlen, T. D., Nur, N., Takekawa, J. Y., and Hanson, J. T. 2002. Management and conservation of San Francisco Bay salt ponds: Effects of pond salinity, area, tide, and season on Pacific Flyway waterbirds. Waterbirds 25:79-92.

Williams, P. B., and Faber, P. B. 2001. Salt marsh restoration experience in San Francisco Bay. J. Coastal Res., Spec. Issue No. 27:203-211. 
Wilson, S., Anderson, E. M., Wilson, A. S. G., Bertram, D. F., and Arcese, P. 2013. Citizen science reveals an extensive shift in the winter distribution of migratory Western Grebes. PLoS One 8(6): e65408; doi 10.1371/journal.pone.0065408.

Ydenberg, R. C., Butler, R. W., Lank, D. B., Guglielmo, C. G., Lemon, M., and Wolf, N. 2002. Trade-offs, condition-dependence and stopover site selection by migrating sandpipers. J. Avian Biol. 33:47-55; doi 10.1034/j.1600-048X.2002.330108.x.

Ydenberg, R. C., Butler, R. W., Lank, D. B., Smith, B. D., and Ireland, J. 2004. Western Sandpipers have altered migration tactics as Peregrine Falcon populations have recovered. Proc. R. Soc. B 271:12631269; doi 10.1098/rspb.2004.2713.

Ydenberg, R. C., Barrett, J., Lank, D. B., Xu, C., and Faber, M. 2017. The redistribution of non-breeding Dunlins in response to the post-DDT recovery of falcons. Oecologia 183:1101-1110; doi 10.1007/ s00442-017-3835-2.

Zuur, A., Ieno, E. N., Walker, N., Saveliev, A. A., and Smith, G. M. 2009. Mixed Effects Models and Extensions in Ecology with R. Springer Science and Business Media, New York. 